\title{
Microplastics in the Environment: Intake through the Food Web, Human Exposure and Toxicological Effects
}

\author{
Concetta Pironti ${ }^{1,+}$, Maria Ricciardi ${ }^{1,+}+\mathbb{D}$, Oriana Motta ${ }^{1, *} * \mathbb{D}$, Ylenia Miele ${ }^{2} \mathbb{D}$, Antonio Proto ${ }^{2}$ \\ and Luigi Montano ${ }^{3,4, *}$ \\ 1 Department of Medicine Surgery and Dentistry "Scuola Medica Salernitana", University of Salerno, \\ Via S. Allende, 84081 Baronissi, Italy; cpironti@unisa.it (C.P.); mricciardi@unisa.it (M.R.) \\ 2 Department of Chemistry and Biology, University of Salerno, Via Giovanni Paolo II, 84084 Fisciano, Italy; \\ ymiele@unisa.it (Y.M.); aproto@unisa.it (A.P.) \\ 3 Andrology Unit and Service of Lifestyle Medicine in UroAndrology, Local Health Authority (ASL) Salerno, \\ Coordination Unit of the Network for Environmental and Reproductive Health (Eco-FoodFertility Project), \\ "S. Francesco di Assisi Hospital", 84020 Oliveto Citra, Italy \\ 4 PhD Program in Evolutionary Biology and Ecology, University of Rome "Tor Vergata", 00133 Rome, Italy \\ * Correspondence: omotta@unisa.it (O.M.); luigimontano@gmail.com (L.M.); Tel.: +39-089-963-083 (O.M.) \\ + These authors contributed equally to this paper as first authors.
}

Citation: Pironti, C.; Ricciardi, M.; Motta, O.; Miele, Y.; Proto, A.; Montano, L. Microplastics in the Environment: Intake through the Food Web, Human Exposure and Toxicological Effects. Toxics 2021, 9 , 224. https://doi.org/10.3390/ toxics 9090224

Academic Editors: Andreu Rico and Roberto Rosal

Received: 31 July 2021

Accepted: 14 September 2021

Published: 16 September 2021

Publisher's Note: MDPI stays neutral with regard to jurisdictional claims in published maps and institutional affiliations.

Copyright: (c) 2021 by the authors. Licensee MDPI, Basel, Switzerland. This article is an open access article distributed under the terms and conditions of the Creative Commons Attribution (CC BY) license (https:// creativecommons.org/licenses/by/ $4.0 /)$.

\begin{abstract}
Recently, studies on microplastics (MPs) have increased rapidly due to the growing awareness of the potential health risks related to their occurrence. The first part of this review is devoted to MP occurrence, distribution, and quantification. MPs can be transferred from the environment to humans mainly through inhalation, secondly from ingestion, and, to a lesser extent, through dermal contact. As regards food web contamination, we discuss the microplastic presence not only in the most investigated sources, such as seafood, drinking water, and salts, but also in other foods such as honey, sugar, milk, fruit, and meat (chickens, cows, and pigs). All literature data suggest not-negligible human exposure to MPs through the above-mentioned routes. Consequently, several research efforts have been devoted to assessing potential human health risks. Initially, toxicological studies were conducted with aquatic organisms and then with experimental mammal animal models and human cell cultures. In the latter case, toxicological effects were observed at high concentrations of MPs (polystyrene is the most common MP benchmark) for a short time. Further studies must be performed to assess the real consequences of MP contamination at low concentrations and prolonged exposure.
\end{abstract}

Keywords: microplastic; nanoplastic; environment; food web; human exposure; toxicological effects

\section{Introduction}

Plastics are widely employed in many applications, ranging from food packaging to technological devices and disposable medical equipment, thus making them present in everyday human life. However, the consequential human exposure to microparticles derived from plastic materials could have, over time, harmful effects. In literature, a large number of studies are dedicated to the transport of microplastics in the food web through air, water, and soil environments; their persistent nature can be very toxic to humans. Plastic debris is defined as microplastics (MPs) by the National Oceanic and Atmospheric Administration (NOAA) when the particles have a diameter lower than $5 \mathrm{~mm}$. The classification of microplastics is also based on their source: microplastics are defined as primary if released intentionally in the environment and secondary if they are released indirectly by deterioration processes. Microbeads and abrasives in personal care products and cleaning formulations are examples of primary MPs intentionally included in products and used in the manufacturing of plastic materials [1]. Secondary microplastics can derive from the deterioration, fragmentation, or improper disposal in the environment of large 
pieces of plastic, such as plastic films, household garbage, atmospheric deposition, and vehicle emissions [2-4]. Mixtures such as paints can release both primary and secondary microplastics: primary when the paint is in its fluid form and secondary if small particles detach from the dried paint (for example, fragments of ships and boats) [5].

Microplastics can have different shapes (fibers, fragments, spheres, beads, films, flakes, pellets, and foam) depending on the original form of the plastics, the deterioration processes occurring on the plastic surface, and the residence time in the environment [6-8]. The potential of microplastics to cause physical harm to organisms is affected by their size and shape [9]. In fact, although large microplastics are not taken up by most plants and soil organisms, small particles (e.g., nanoplastics) can be easily taken into cells, thus generating an environmental risk $[10,11]$.

Concerning plastic shape, some studies suggest that fibers are more toxic on marine invertebrates with respect to fragments and spheres having the same polymer matrix $[12,13]$. In addition to petroleum-based plastic fibers, man-made cellulose fibers (e.g., viscose/rayon) have also been detected in different environmental matrices (deep-sea sediment [14], macroinvertebrates [15], fishes [13,16]), thus increasing the interest of the scientific community in this kind of plastic pollution, which is usually underestimated. This type of fiber is biodegradable in the natural aquatic environment, so it is not considered an environmental issue in itself. However, the additives it contains may be harmful to aquatic organisms.

In fact, the presence of organic and inorganic additives and traces of monomers, metals, or other compounds that can be released represents a more toxic source of pollution for human health than the MP fragments themselves [17-19]. For example, chemicals such as bisphenol A [20] and phthalates [21] are often found in association with microplastics; these endocrine disruptors can be very hazardous for humans [22-24]. Other adverse effects on the environment derive from the fact that the MPs can also act as vectors for other contaminants [25] (e.g., potential human pathogens [26-28], organic pollutants [29], heavy metals [30-33]). In fact, the adsorption of persistent organic pollutants (POPs), mainly polycyclic aromatic hydrocarbons (PAHs), polychlorinated biphenyls (PCBs), polybrominated diphenyl ethers (PBDEs), and dichlorodiphenyltrichloroethane (DDT) on microplastics has been reported [29]. Trace elements were found in combination with microplastics in the marine zooplankton of the Mediterranean Sea. Aluminum, iron, chromium, zinc, nickel, molybdenum, manganese, lead cobalt, and copper were found at concentrations of $\mathrm{mg} / \mathrm{kg}$ while arsenic, vanadium, rubidium, and cadmium at level of $\mu \mathrm{g} \mathrm{kg}^{-1}$ [30]. The levels of aluminum, copper, and zinc registered were comparable with the values found in microplastics collected in England and Brazil, while the levels of iron and manganese were lower in the samples collected in the Mediterranean Sea [31-33].

Microplastics may concentrate in the human body through various exposure pathways (see paragraph on "Implication of microplastic contamination on human health"), such as inhalation of dust and direct consumption of food contaminated by microplastics. In fact, the maximum estimated intakes of microplastic from dust ingestion for adults and children are about 1000 and 3000 particles per year, respectively [34]. At present, knowledge of the effects and toxicity of microplastics to humans is very limited, and the research on the trophic transfer of microplastics in the food web to humans is key to preventing microplastic contamination problems.

This review covers some environmental routes (water, air, and soil) of microplastics contamination into the food web, describing their effects on human health, and presents new and relevant studies on their occurrence, fate, and behavior.

\section{Methodology}

The authors thoroughly reviewed the literature related to microplastics, finding that current research is predominantly focused on environmental contamination rather than human health interactions. This review went through under a three-pillar approach: (1) delineation of the urgency and seriousness of microplastics in the food web by emphasizing 
the various ways that microplastics interact with the human body; (2) impacts of microplastics on water, air, and soil properties through multiple aspects, as well as the potential risks when dispersed into other environment media, transferred along the food chain, and accumulated by animals, plants, and humans; (3) determination of contamination and accumulation of MPs in water, soil, air, and food, particle toxicity, and the proposal of future research directions according to the existing literature. The keywords "microplastic", "environment", "food web", "human exposure", and "toxicological effects" were selected individually or jointly to search for relevant information on Web of Science, Scopus, and Google Scholar. Key literature published between 2004 and 2021 (up to June) were assimilated and analyzed.

\section{Occurrence, Analysis, and Abundance of Microplastics in the Environment}

Microplastic pollution was first observed in the marine environment: in the 1970s, spherules, disks, and pellets were detected on the surface of the Sargasso Sea [35], on the coasts of New England [36], in the surface waters of the Atlantic Ocean [37], and in the surface waters of the Pacific Ocean [38]. Recently, the attention of researchers has moved to wastewater, rivers, and lakes [39-43]. Due to the increasing interest in this field, several review articles $[3,44-49]$ were published in the last few years, with the aim of giving an overview of microplastic presence in different water matrices all over the world, analytical methods for their detection, and possible consequences to human health $[2,7,39,50,51]$. The occurrence of microplastics in the water environment was widely discussed in our recently published review, which focused on their abundance in different water matrices and their distribution worldwide [52]. In contrast, the present review mainly deals with the transport of this contaminant to humans through the food web, with only an introduction of the pollution of the different environmental compartments.

As regards the origin of MP contamination in water environments, the main sources are improperly disposed plastic wastes from land and, to a lesser extent, derivatives from marine activities, such as the fishing industry employing plastic equipment $[51,53]$. The fragmentation of plastic debris in water leads to the contamination of aquatic species through active and passive intakes, with consequent transfers within the food web [54].

More recently, microplastics have been recognized as air pollutants [55-59]. Alongside other atmospheric contaminants such as nitrogen oxides [60-62], hydrogen sulfide [63,64], carbon dioxide $[65,66]$, persistent organic pollutants [67], and BTEX [68,69], their concentration should be regularly monitored to ensure human safety. Several studies have shown that atmospheric microplastic particles can be carried to remote areas by atmospheric events such as winds [70-73], ocean currents [2,74,75], river outflow, and drift [76,77]. Airborne MPs may be deposited in aquatic environments and soils via dry or wet deposition [78], with a consequent spatial distribution and temporal variability of their abundance $[79,80]$. As a consequence, microplastics have been detected even in remote areas such as the Antarctic and the South Indian Ocean.

The estimated amount of annual plastics discharged to the soil is much higher than that released in the oceans [81], so the terrestrial environment can be considered an important sink for microplastics $[82,83]$. However, microplastic pollution in the soil environment has been largely overlooked for several years [84,85], gaining attention since 2012, when Rilling [86] identified the possibility of microplastic occurrence in the terrestrial environment and the need for studies for their estimation. The low number of investigations is probably due to the unavailability of suitable analytical methods for microplastics in soils [87]. Plastic mulch films, compost and municipal solid waste, biosolids such as anaerobic digestate and sewage sludge, irrigation and flooding of wastewaters, atmospheric deposition, illegal dumping of waste, and plastic-coated fertilizers represent the principal sources of microplastics in soil [81,88-92].

The collection and treatment of samples are the most important steps to obtaining a satisfying determination of microplastic pollution without contamination. Different sampling techniques are required according to the type of environmental matrix considered. 
For the water compartment, the main sampling methods are sediment recovery from the seafloor, beaches, and estuaries, beachcombing for the shoreline, observation by divers, use of marine trawls to collect particles within the water column, and examination of plastic fragments ingested by marine organisms [2,7].

Regarding atmospheric microplastics, most of the studies have employed a passive sampling of deposited material [93-95], while only a few studies have used active sampling [96-98], often in comparison with passive ones.

The two sampling methodologies provide different information regarding microplastics in the air. In particular, passive samplers give an estimation of the number of deposited microplastics onto the surface of a certain place during a specific time-lapse, while active devices return the number of microplastics in the air mass that may not be deposited [99].

Once sampling has been carried out, the analysis of MPs can be done through several procedures such as separation, identification, and quantification. Sieves usually achieve the first step of microplastics separation, with mesh sizes ranging from 0.038 to $4.75 \mathrm{~mm}$ and filters with small mesh sizes $(0.02-5 \mu \mathrm{m})[100,101]$. For small particles (dimensions $<1 \mu \mathrm{m}$ ), many studies have reported the use of active (e.g., field flow fractionation technique) [102] and passive separation (e.g., chromatographic techniques such as hydrodynamic chromatography) $[103,104]$.

Particle visualization, as well as the evaluation of color, shape, and light transmission, is important for identifying microplastics in sample materials or debris (e.g., shell fragments, algae, sand, and glass) [7] and distinguishing plastic from non-plastic particles [105]. Large microplastics (1-5 mm) are identified with the naked eye, and an optical microscope can be used for smaller microplastics to obtain images for analysis, which provide the shape and number of the microplastic particles. More advanced techniques, such as SEM-EDS (scanning electron microscopy coupled with energy-dispersive X-ray spectroscopy) [106], were recently reported in the literature to characterize the morphology of ultra-small plastic particles and facilitate the differentiation of microplastics from other plastic-like particles [107]. Lastly, the characterization of samples in terms of chemical composition, i.e., polymer type, is mainly performed by FT-IR (Fourier transform infrared spectroscopy) and Raman spectroscopy [108]. These are useful techniques for identifying the polymeric composition of microplastics of different types (with sizes $\leq 2 \mu \mathrm{m}$ ) since they require small sample amounts and limited sample preparation. Moreover, these spectroscopies are complementary vibrational techniques. Generally, signals with strong IR intensity have weak Raman intensity and vice versa. For instance, carbonyl groups, being polar functional groups, are well detected by IR, whereas aromatic bonds and double bonds are better identified using Raman [109].

The analytical techniques described in this section are used for the identification of microplastics in all the environmental compartments, i.e., water, air, and soil. The quantification of MPs is still a great challenge due to their special chemical and physical properties (very high molecular weights, poor solubility in most solvents). Although new accurate and sophisticated analytical methods have been reported for microplastic detection and characterization, FT-IR and Raman spectroscopy remain the most commonly used for identifying the polymeric composition of microplastics, accompanied by visual characterization through optical microscopy.

\section{Microplastic Transport in the Food Web and Consequent Human Exposure}

As reported above, microplastics can be generated through several mechanisms and can be transported across different environmental compartments, reaching the food web and, finally, the human body. Figure 1 shows the main pathways of food contamination through soil/water/atmosphere. Human ingestion of contaminated food and beverages is a concern $[110,111]$, even if it seems to be unappreciated compared to environmental implications. 


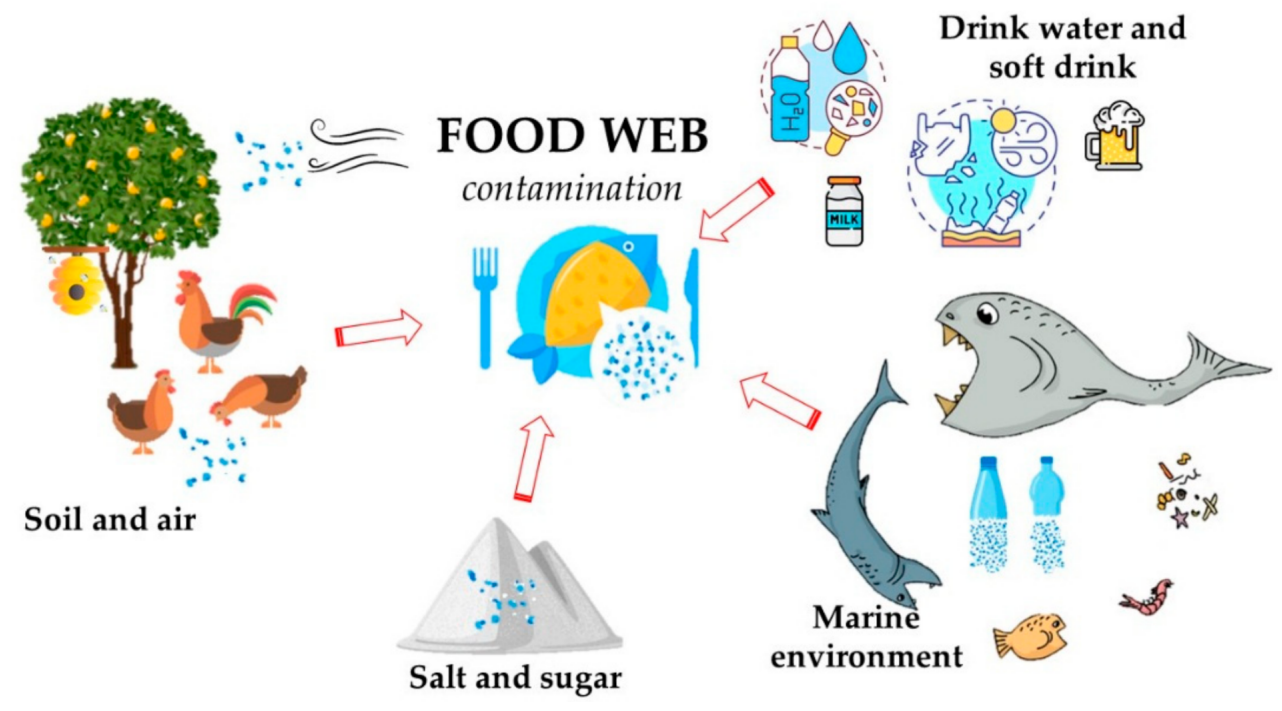

Figure 1. Scheme of food web contamination due to MP pollution.

In this paragraph, we discuss peer-reviewed papers on MP contamination in edible animal species (seafood and chicken) and food samples such as salt, sugar, honey, milk, fruit, soft drinks, and drinking water.

Food and beverage samples must be pretreated to avoid large errors in the results. For example, drinking water samples were filtered, in parallel, through stainless steel filters [112]. A flowmeter was connected to all the outlet tubes of the filtration units to quantify the volume of filtered water. At each sampling position, the setup was primed for ten minutes prior to applying filters. Finally, the filters were transferred to glass Petri dishes, covered with $70 \%$ ethanol, and stored at $-20^{\circ} \mathrm{C}$ until further processing. Salt samples can be treated with hydrogen peroxide to digest possible organic content [113]. Fish samples can be caught using different types of gear and transported to fishing harbors in ice chests and later transferred to another ice chest and stored at $-20^{\circ} \mathrm{C}$ before the analysis [114]. Similarly, chicken feces and other food samples are frozen before the analysis to avoid decomposition [115].

Sometimes fishes and mussels are collected from the sea and kept alive to study how they interact with MPs. In these cases, they can be held in fiber-glass tanks with artificial seawater to acclimatize to laboratory conditions, and then microalgae or shrimps are added to feed the animals $[116,117]$.

Once the exposure time is completed, it is necessary to extract the MPs and remove fats, proteins, sugars, and other substances through digestion with acids, alkali, oxidizing agents, and enzymes. Sometimes, multiple digestion steps are required to improve the analysis. The analytic techniques for particle characterization and chemical composition are the same discussed in the paragraph "Occurrence, analysis, and abundance of microplastics in the environment".

\subsection{Seafood}

The marine environment is the most studied system for MP contamination, and sea products (e.g., wild animal species, algae, sea salts) [118] are one of the primary sources of food for humans [119]. Consequently, several studies have investigated microplastic occurrence and abundance in marine species, expressing MP concentration as the number of particles/g or particles/individual [120-138]. There are two different mechanisms to describe how MPs reach the organs of fish. MPs may be captured actively (by confusion with prey), passively (e.g., gill water filtration), and through the ingestion of contaminated prey [139].

Shellfish (including crustaceans and bivalves) and other fish species are often contaminated with microplastics. Microplastics were detected in the 25 species contributing 
most to global sea fishing, including the Atlantic cod (Gadus Morhva), the European hake (Merluccius Merluccius), the red mullet (Mullus Barbatus), and the European pilchard (Sardina Pichardus) [114]. Miranda and Carvalho-Souza [140] also found microplastics in the digestive tract of two important species of edible fish (Scomberomorus Cavalla and Rhizoprionodon LandII) from the Brazil's eastern coast, although, in some cases, this would not be a big health concern as the GI tract is discarded during processing. However, scientific studies have analyzed the accumulation of microplastics in other species such as D. Labrax, T. Trachurus, and S. Colias specimens from Portuguese coastal waters [114,141]. In this case, a different amount of plastic debris that could be explained by various mechanisms of contamination (passive, active, and through contaminated prey) was observed for each species. $S$. Colias showed a higher percentage of microplastic contamination in the gastrointestinal tract $(62 \%)$ than the other species $(42 \%)$, probably due to some distinct ecological features (e.g., time spent in areas closer to shore, feeding ecology) and physiological differences (e.g., water filtration rates, elimination processes) [114].

Among the 150 fishes analyzed, the percentage value obtained of $35 \%$ is comparable to the corresponding values reported in the literature: $19.8 \%$ of 263 fishes from Portuguese coastal waters, $38 \%$ of 120 fishes from the Monolego River estuary in Portugal, 58\% of 1337 fishes from the Mediterranean Sea, and 65\% of 178 fishes from the Red Sea [141]. In the Persian Gulf, a wide variety of pelagic and benthic species was investigated: about 128 marine organisms, divided into 3 fish species, 1 prawn species, and 1 crab species. The results found that the MPs were located in the muscles and gills of the individuals [142]. In this case, the adsorption in muscles could show toxicological effects since all particles were equally transferred to the next level of the food web. Microplastic fibers were recently detected on the external surface and in the gastrointestinal tract of clupeid fishes (larval and juvenile stages) from the Mediterranean Sea, i.e., Sardina pilchardus (0.53 items/specimen) and Engraulis encrasicolus ( 0.26 items/specimen). Since these clupeids are among the main food sources for several marine species, these results give rise to concern relating to the possible transfer of microplastics through the marine food web and into humans [109].

The uptake of MPs is also influenced by the chemical and physical composition of water, in particular by salinity. A study of fishes in the Saudi EEZ of the Arabian Gulf, based on 15 individuals of Lethrinus nebulosus, 20 Gerres acinaces, 20 Siganus canaliculatus, 6 Liza parsia, 10 Scomberomorus commerson, 20 Euthynnus affinis, 20 Epinephelus coioides, 20 Rastrelliger kanagurta, and 9 individuals of Carangoides malabaricus, indicated that only $5.71 \%$ of samples ingested MPs. The lower value is probably due to the presence of microplastics in the sea surface microlayer and, consequently, less availability for ingestion by fishes [139]. In the marine food web, consumers or predators can ingest MPs through prey items such as polychaetes, mollusks, small crustaceans and arthropods, annelids, and fish larvae. So even though the gastrointestinal tract is discarded during processing, the presence of MPs in the gastrointestinal tract of marine organisms has raised concern worldwide as seafood can be a significant source of MPs in humans [143-146]. A study on the gastrointestinal tracts of tiger shrimp (P. monodon) and brown shrimp (M. monocerous), commercially important shellfish species of Bangladesh, evaluated the presence of MPs averaging $3.40 \pm 1.23$ and $3.87 \pm 1.05$ particles/g of the gastrointestinal tract; FTIR data confirmed particles of polyamide- 6 and rayon polymers, the common raw materials of ropes, fishing nets, floats, fish baskets/bags, and coatings used in the sea [147].

Moreover, the contamination of MPs involved not only fish from the sea; this could be a warning for freshwater fishing and fish farming industries to introduce more controls. Cultured organisms can be exposed to high levels of MPs, as evidenced by the analysis of fish meals from three different Malaysian commercial brands [148]. In the study, a total of 336 particles was isolated, and $64.3 \%$ were identified as MPs; micro-Raman spectroscopy confirmed that the most abundant isolated polymer was PE (63.0\%), followed by PP (27.8\%), PET (8.8\%), and NY (0.4\%).

A useful tool for quantifying the level of microplastic contamination within the freshwater food web is stable isotope analysis [149]. This technique measures the relative 
abundance of stable isotopes, giving an isotopic ratio, expressed as $\delta$ in \%o [150,151], and providing information about the origin of a sample [152]. It has been widely used in food analysis [153], medical diagnostics [154], monitoring of air quality [155-157], and characterization of commercial cleaning products [158]. It has been recently employed to evaluate the presence of microplastics [159] and to discriminate between polymer sources (petroleum and plant-derived) $[160,161]$. The carbon stable isotope ratio $\left(\delta^{13} \mathrm{C}\right)$ and nitrogen stable isotope ratio $\left(\delta^{15} \mathrm{~N}\right)$ were used to quantify trophic niches for macroinvertebrates and fish within the Garonne River. The abundance of ingested microplastics varied between macroinvertebrates and fish and was not significantly related to pollution; moreover, it increased with the size of organisms and was affected by the origin of the resources consumed by fish. The authors assert that results of isotopic analysis suggest the absence of microplastic bioaccumulation in freshwater food webs and the dominance of direct (accidental) consumption; therefore, the stable isotopic ratio is very useful for a deeper understanding of microplastic ingestion by wild organisms [149].

These studies will not only be beneficial to understanding the distribution and migration of microplastics in marine ecosystems but also provide an important reference for the protection and governance of seafood.

\subsection{Salt for Human Consumption}

In the last few years, several studies regarding the microplastic contamination of salt intended for human consumption [162-170] have been published and discussed [171-174]. Salts provide essential nutrition elements and, thanks to their chemical characteristics and low cost, are used in food preservation methods (e.g., fruits, cheese, cereals, drinks). Other uses for salt, for example, are in the cosmetic and personal care product industry and the pharmaceutical industry (as an additive, stabilizer, and thickener).

MPs have been found in the commercial salts of 128 brands from 38 different sources in numerous countries spanning over five continents in the period 2015-2018 [173]. MP abundance in table salt was different among the countries under study: the lowest values were detected in China (600 particles/kg) [170] and the United States (800 particles/kg) [166], while higher values were discovered in Italy (8000 particles/kg) [168], Indonesia $(10,000$ particles $/ \mathrm{kg})$ [165], and Croatia (20,000 particles/kg) [168]. The particles identified in sea salt were made of cellulose, cellophane $(\mathrm{CPH})$, polyethylene-vinyl acetate (PEVA), PA, polyacrylonitrile (PAN), polyalkene, poly(1-butene), PET, poly(metylacrylate), $\mathrm{PP}$, phenoxy resin (PR), polyurethane (PU), polyvinyl chloride (PVC), and paraffin wax. The results of a meta-analysis [171] proved that the microplastic content in salt strongly depends on its origin; in particular, sea salt is the most contaminated, followed by lake salt, rock, and well salt. The microplastic contamination of salts can derive from the alteration of larger plastic pieces through biological, photo, and/or mechanical degradation in the environment or from the direct input of particles from industrial processes and the manufacture of a wide diversity of everyday-use products. The high amount of microplastics in sea salt derives from the fact that it is produced from the evaporation of seawater, which often contains harmful microplastics. Hence, recently, a coagulation process was developed for a clean sea salt production by removing microplastics from seawater, showing interesting results [175].

Consequently, maximum human exposure is estimated to be 6110 microplastic particles per year, confirming salt as a microplastic carrier. To illustrate human risk, several authors estimated the annual consumption of microplastic particles through sea salt. The values are 37 [164], 64-302 [162], 40-680 [166], 510 [163], and 1000 particles [170] based on human ingestion of $5 \mathrm{~g}$ of salt per day, the recommended intake threshold by the World Health Organization [176]. However, the actual salt intake can be much higher (10 g/day worldwide [177]) than the recommended one, thus increasing the human ingestion of MPs derived from salt. 


\subsection{Drinking Water}

Freshwater bodies are the predominant drinking water source for human consumption. In literature, some scientific papers introduced the role of potable water as a suspect potential source of MPs [178-186]. The presence of fibers in surface water is, therefore, presumably caused by the inflow of sewage water. Freshwater has been shown to contain PE and PP, comprising up to $>90 \%$ of MPs in drinking water, and also PET, PS, PVC, polyester (PES), PA, polytetrafluoroethylene (PTFE), and RY, the materials commonly used in various products, in particular, food and cosmetic packaging, houseware, and toys [174]. Some studies analyzed water samples in Germany, including raw water, drinking water, tap water, and bottled water $[181,182,184]$. Water samples taken at different positions within the drinking water supply chain (raw water and drinking water) have shown an average microplastic concentration of 700 particles/L (range 0-7000 particles/L) [181]. The detected microplastic particles were small fragments (size range 50-150 $\mu \mathrm{m}$ ) of polyester, polyvinylchloride, polyethylene, polyamide, and epoxy resin, probably introduced during drinking water purification and transport. Other authors have investigated microplastic abundance in bottled water from diverse packages (single-use plastic bottles, reusable plastic bottles, beverage cartons, and glass bottles); however, no statistical differences were observed among samples $[182,184]$. Microplastics in the size range of $5-100 \mu \mathrm{m}$ were detected in concentrations from $11 \pm 8$ (beverage cartons) to $118 \pm 88$ (returnable plastic bottles) particles/L [184]. In contrast, a higher microplastic amount in mineral water from reusable PET bottles (average $4889 \pm 5432$ microplastics/L) compared to single-use PET bottles ( $2649 \pm 2857$ particles/L) and also a high microplastic content ( $3074 \pm 2531$ microplastics/L) in glass bottles were observed in the size range of 1-5 $\mu \mathrm{m}$ [182]. Microplastic abundance in raw and treated water was determined from three drinking water treatment plants in urban areas of the Czech Republic [183]. Microplastic content was significantly lower in treated (from $338 \pm 76$ to $628 \pm 28$ particles/L) compared to raw water (from $1473 \pm 34$ to $3605 \pm 497$ particles/L), and most of the particles were within the size range of $1-10 \mu \mathrm{m}$.

The detected microplastic concentrations in treated water are not negligible and suggest that potable water could be an important source of microplastics to humans. Recently, the World Health Organization [187] has reported that the microplastic content in tap water is about 5 particles/L, with a consequent daily dose of microplastics of 10 particles, considering a human water intake assumption of 2 L/day [188]. A significant increase in the amount of microplastic intake must be considered in individuals who drink water only from plastic bottles compared to those who consume only tap water (additional 90,000 annual microplastic particles compared to 4000).

\subsection{Soft Drinks}

Beverages intended for human consumption are divided into groups of alcoholic and non-alcoholic drinks. Beers, wines, and spirits are classified as common alcoholic drinks, while non-alcoholic drinks include tea, coffee (hot and cold), soft drinks, milk, chocolate, carbonated, and non-carbonated sweetened drinks.

In Mexico [189], a total of 57 beverage products, including cold tea, soft drinks, energy drinks, and beers, was investigated to develop baseline data on the levels of MPs. Chemical characterization results allow for the distinction of different forms of MPs (fibers and fragments) and various sizes of 0.1-3 mm with different colors (blue, red, brown, black, and green). The chemical nature of MPs obtained by micro-Raman spectroscopy indicated contamination from synthetic textiles and packaging in the beverage products; indeed, the particles identified were PA, poly(ester amide), acrylonitrile, butadiene, styrene, and PET, the most common raw materials of these commercial products [189]. A possible source of contamination could be the water used in the bottling industry production of soft drinks, which comes from various supply sources: groundwater, surface water, a public water network, or rainwater [190]. Considering that the international market of drinking water has an annual volume of over 245 billion liters, small quantities of MPs in drinks can also have harmful effects on human health due to accumulation and interaction with other 
compounds. An appropriate study in vivo is necessary to preserve and understand all possible implications.

In German beers, a 2014 study investigated microplastic contamination and found fibers, fragments, and granules after filtration through a $0.8 \mu \mathrm{m}$ cellulose filter, except for wheat beers that could percolate and were filtered through a $40 \mu \mathrm{m}$ sieve [191,192]. However, there were many criticisms of the results because researchers affirmed that contamination could not have originated from the raw material, but there were artifacts due to laboratory contaminations. In 2018 [166], the MP contamination of American beers was evaluated: the samples were filtered with an $11 \mu \mathrm{m}$ pore size, and the authors postulate that product processing might be the most important factor explaining human contamination.

\subsection{Milk}

Dairy milk products are a part of globalized commodities for regular income; world exports expanded to 75 million tons (in milk equivalents), and global milk output in 2018 was estimated at 843 million tons [193]. However, the industrial process of milk production has been subjected to many technological developments to improve hygiene and human health, which have influenced milk composition [194]. Considering the intense processing of milk, the possible risks of milk contamination from microplastics may occur from poor cleanliness procedure equipment, the surrounding environment, as well as water supply conditions and the inadequate handling of milk. The presence of MPs in dairy milk products was detected in Mexico [195], where 23 milk samples from 5 international and 3 national brands were analyzed. All samples analyzed included microplastics. Scanning electron microscopy coupled with energy-dispersive X-ray spectroscopy (SEM-EDS) was used to examine the surface morphology and elemental composition of microplastics in milk samples. A total of 150 microplastic particles were confirmed in 23 milk samples, with an average concentration of $6.5 \times 10^{3}$ particles $/ \mathrm{m}^{3}$, lower than any reported levels in liquid food products, confirming the ubiquity of MPs in samples and showing variability in the range of $3-11 \times 10^{3}$ particles $/ \mathrm{m}^{3}$ [195]. The most common contaminants in milk samples are the thermoplastic sulfone polymers that are used in the ultrafiltration and microfiltration membranes in food and dairy industry processing. High pressure and continuous chemical and physical stress can damage the membranes, peeling off particles from filters, and, thus, may be a source of microplastics in fluid milk samples. The release of microplastics from milk raises serious concerns because the main consumers of milk are infants.

Infant feeding bottles, commonly made of PP, can release microplastics in milk, as evidenced in the paper of Li et al. [196]. In this study, the authors also estimated the intake of MPs on all the continents. The average daily consumption of PP MPs by infants was estimated to be 1,580,000 particles per capita, with a range of 14,600-4,550,000 particles, depending on the region. Infants in Africa and Asia have the lowest potential exposure to MPs from PP bottles, with rates of 527,000 and 893,000 particles per day, respectively. Infants in South America have medium exposure levels (1,010,000 particles per day), whereas Oceania, North America, and Europe have the highest levels, corresponding to $2,100,000,2,280,000$, and 2,610,000 particles per day, respectively. The average value corresponds to about 3000 times the total adult consumption of MPs from water, food, and air (up to 600 particles per day for adults).

\subsection{Honey, Sugar, and Fruit}

The analysis of 19 samples of honey coming from different countries revealed a high concentration of microplastic particles [197]. In 2019, the Swiss Beekeepers Association started new research to understand the origin of MP contamination in honey. Therefore, they discriminated beehives made of wood from those made of polystyrene to explore the significant contamination source in honey. For these particle classes, they were able to identify the particle materials using attenuated total reflection-Fourier transform infrared spectroscopy (ATR-FTIR) and Raman techniques, which, in some cases, even allowed them 
to relate the particles to their specific origin. The results do not provide any evidence for notable contamination in honey from environmental sources, but some microscopic particles could be related to beekeeper activities [198]. Microplastics were also discovered in honey from Ecuador, with a concentration of 54 and 67 particles/L in industrial and craft honey, respectively [199]. This microplastic contamination of food products probably originated from atmospheric contribution during production processes.

The mean values of microplastics in sugars (excluding the cane sugar sample) were $217 \pm 123$ fibers $/ \mathrm{kg}$ and $32 \pm 7$ fragments $/ \mathrm{kg}$, with the maxima of 388 and 270, respectively. For these samples, no distinction was made between colored and transparent particles. International sugar suppliers usually offer purities $\geq 99.8 \%$, where these sugars will contain a maximum of $0.2 \%$ foreign matter. However, despite the large numbers of foreign particles found in both honey and sugars, they will most probably not exceed any governmental or industry limits [197].

Very recently, microplastics were detected, for the first time, in edible fruits $(52,600-307,750$ particles/g) and vegetables $(72,175-130,500$ particles/g) in the size range of 1.36-3.19 $\mu \mathrm{m}$, with apples and carrots being the most contaminated samples (estimated daily intakes of MPs in the range of $2.96 \times 10^{4}-1.41 \times 10^{6}$ particles $/ \mathrm{kg} /$ day) [200].

\subsection{Chicken, Cows, and Pigs}

In 2017 [115,201], MP transfer from soil to chickens was investigated for the first time in traditional Mayan home gardens in Southeast Mexico. The authors analyzed the concentration of MPs in soil, earthworm casts, chicken feces, crops, and gizzards (used for human consumption) and observed that the concentrations increased from soil $(0.87 \pm 1.9$ particles $/ \mathrm{g})$ to earthworm casts $(14.8 \pm 28.8$ particles $/ \mathrm{g})$ to chicken feces (129.8 \pm 82.3 particles/g). Chicken gizzards contained $10.2 \pm 13.8$ microplastic particles/g, while no microplastic was found in crops. Most recently, it has also been reported that microplastic contaminants can be present in chicken meat and feces [202]. Other researchers have evaluated the use of a rapid method based on attenuated total reflection mid-infrared (ATR-MIR) spectroscopy combined with chemometric techniques to identify the level of contamination in chicken meat with microplastics polystyrene (particle size $100 \mu \mathrm{m}$ ) and polyvinyl chloride (particle sizes $3 \mu \mathrm{m}, 100 \mu \mathrm{m}$, and 2-4 mm) [203].

The occurrence of microplastics in livestock and manure has been reported in 19 different farms in South China, where pigs, poultry, and cows are raised [204]. PP and PE in colorful fibers and fragment types were the most abundant MPs. Livestock and poultry animals can eliminate MPs when eating polluted feeds. MPs can also reside in the digestive system, despite the high levels of digestive juices; thus, MPs can pass through the digestive system and remain in the manure. After the contaminated feces is used for composting, agricultural soil can be polluted by the MPs present in the compost. Another source of MP contamination for meat is the packaging used: extruded polystyrene microplastics can contaminate meat at 4-18.7 particles per $\mathrm{kg}$ of food [205].

These are very small examples of MP contamination in edible animals, and they are not sufficiently representatives of a real meat contamination issue.

\subsection{Some Considerations of Food Web Contamination}

Based on the studies discussed above, great efforts have been devoted to microplastic detection in sea products, drinking water (raw, treated, and stored in different packages), and salts for human consumption, while only a few studies have been conducted on other foods such as honey, sugar, fruit, and chickens. This higher number of studies is probably due to the easy transport of microplastics from a polluted water environment to related food products. Several factors are responsible for an MP presence in food products. The contamination can be related to environmental sources (contamination of water, soils, and air) [197] and manufacturing processes such as the materials used during the filtration step of beer and milk [199]. 
MP contamination can also be due to packaging, such as bottled drinking water, beer, milk, and refreshments [206], extruded polystyrene for meat [205], and take-out food containers. In a study published in 2020, four plastic containers made of polypropylene (PP), polystyrene (PS), polyethylene terephthalate (PET), and paperboard coated with PE were analyzed: the highest microplastic abundance was found in the containers made of PS [207]. Based on the MP abundance of food containers and take-out order frequency, human microplastic intake is estimated as 12-203 items per week. The packaging material has less effect on beer since, in most cases, beer is packaged in glass bottles and aluminum cans [199].

MP occurrence in food and beverages is recapped in Table 1. The estimated intake of MPs through inhalation and ingestion is reported in Table 2. Among various foods investigated, salt is the one that releases the least microplastics, while a high intake of microplastics can occur through milk stored in PP bottles used for infants. As regards meat and seafood, the dose of MPs ingested depends on dietary habits: for example, in the UK, where people eat less seafood, the MP intake is minor compared to Mediterranean countries [208].

Table 1. Occurrence and quantification of microplastics in foods and beverages.

\begin{tabular}{|c|c|c|c|c|c|}
\hline Sample & Sampling Location & $\begin{array}{c}\text { Abundance } \\
\text { Average (Range) }\end{array}$ & $\begin{array}{l}\text { Size } \\
\text { Range }\end{array}$ & $\begin{array}{l}\text { Polymer } \\
\text { Type }\end{array}$ & Ref. \\
\hline \multicolumn{6}{|l|}{ Seafood } \\
\hline European anchovies & $\begin{array}{l}\text { Mediterranean Sea (Gulf } \\
\text { of Lions) }\end{array}$ & - & $0.124-0.438 \mathrm{~mm}$ & $\begin{array}{c}\mathrm{PE}, \\
\text { styrene/acrylonitrile }\end{array}$ & [123] \\
\hline $\begin{array}{c}\text { Bivalves (Mytilus edulis } \\
\text { and } \\
\text { Crassostrea gigas) }\end{array}$ & Germany and Brittany (FR) & $0.36-0.47$ particles $\mathrm{g}^{-1}$ & $>0.005 \mathrm{~mm}$ & 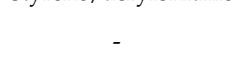 & [136] \\
\hline Mussels (Mytilus edulis) & $\begin{array}{l}\text { French-Belgian-Dutch coastline } \\
\text { (FR, BE, NL) }\end{array}$ & $0.2-0.5$ particles $\mathrm{g}^{-1}$ & $0.015-1 \mathrm{~mm}$ & - & [135] \\
\hline $\begin{array}{l}\text { Dogfish, hake, red } \\
\text { mullet }\end{array}$ & $\begin{array}{l}\text { Galician coast, Cantabrian coast, } \\
\text { Gulf of Cadiz, Spanish } \\
\text { Mediterranean coast (ES) }\end{array}$ & $\begin{array}{c}1.56 \pm 0.5 \\
\text { particles/individual }\end{array}$ & $0.38-3.1 \mathrm{~mm}$ & - & [121] \\
\hline Semipelagic fish & $\begin{array}{l}\text { Mallorca and Eivissa (Balearic } \\
\text { Islands, ES) }\end{array}$ & $\begin{array}{c}3.75(2.47-4.89) \\
\text { particles/individual }\end{array}$ & $0.5 \mathrm{~mm}$ & - & [132] \\
\hline $\begin{array}{l}\text { Pelagic and } \\
\text { demersal } \\
\text { fish }\end{array}$ & Plymouth (UK) & $\begin{array}{c}1.90 \\
\text { particles/individual }\end{array}$ & $0.13-14.3 \mathrm{~mm}$ & PA, cellulose, RY & [131] \\
\hline $\begin{array}{l}\text { Benthic and } \\
\text { pelagic fish }\end{array}$ & Portugal coast $(\mathrm{PT})$ & $\begin{array}{c}0.27 \pm 0.63 \\
\text { particles/individual }\end{array}$ & $\begin{array}{c}0.217-4.81 \\
\text { (average } 2.11 \text { ) } \mathrm{mm}\end{array}$ & $\begin{array}{l}\text { PP, PE, ALK, RY, } \\
\text { PES, NY }\end{array}$ & [133] \\
\hline $\begin{array}{l}\text { Different fish } \\
\text { species }\end{array}$ & $\begin{array}{l}\text { Mediterranean coast of Turkey } \\
\text { (TR) }\end{array}$ & $\begin{array}{l}2.36 \\
\text { particles/individual }\end{array}$ & average $0.656 \mathrm{~mm}$ & $\begin{array}{c}\text { polystyrene: } \\
\text { isoprene, } \mathrm{PE}, \mathrm{PP}\end{array}$ & [126] \\
\hline $\begin{array}{l}\text { Red mullet } \\
\text { (Mullus surmuletus) }\end{array}$ & $\begin{array}{l}\text { Palma, Port d'Andratx, Port } \\
\text { d'Alcúdia, Cala Ratjada and } \\
\text { Santanyí (Mallorca, ES) }\end{array}$ & $\begin{array}{l}(0.32-0.68) \\
\text { particles/individual }\end{array}$ & - & $\begin{array}{c}\text { PET, CPH, } \\
\text { Polyacrylate, PAN }\end{array}$ & [120] \\
\hline $\begin{array}{l}\text { Deep benthic } \\
\text { invertebrates }\end{array}$ & Rockall Trough, Scotland (UK) & $1.582 \pm 0.448$ particles $\mathrm{g}^{-1}$ & $\begin{array}{c}0.023-6.25 \\
\text { (average } 1.191 \text { ) } \mathrm{mm}\end{array}$ & ALK, PES & [124] \\
\hline Benthic organisms & $\begin{array}{l}\text { South Yellow Sea (North China } \\
\text { and South Korea, CN, KR) }\end{array}$ & (1.7-47.0) particles $\mathrm{g}^{-1}$ & $0.05-5 \mathrm{~mm}$ & PP, PE, PS, PET, NY & [137] \\
\hline $\begin{array}{c}\text { Mussels } \\
\text { (Mytilus edulis) }\end{array}$ & Coastal water of China $(\mathrm{CN})$ & $\begin{array}{l}0.9-4.6 \\
\text { particles/individual } \\
1.5-7.6 \text { particles } \mathrm{g}^{-1}\end{array}$ & $0.033-4.7 \mathrm{~mm}$ & CPH, PET, PES & [129] \\
\hline $\begin{array}{l}\text { Different fish } \\
\text { species }\end{array}$ & Rapa Nui (Easter Island, CL) & particles/individual & $0.2-5 \mathrm{~mm}$ & PE, PP & [134] \\
\hline $\begin{array}{l}\text { Bivalve (oyster, mussel, } \\
\text { Manila clam and } \\
\text { scallop) }\end{array}$ & South Korea (KR) & $\begin{array}{c}0.97(0-2.8) \\
\text { particles /individual } \\
0.15(0-1.8) \text { particles } \mathrm{g}^{-1} \\
\text { Stomach: } 1.96 \\
\text { particles /individual and }\end{array}$ & $0.1-0.2 \mathrm{~mm}$ & $\begin{array}{l}\text { PE, PP, PS, PES, } \\
\text { PEVA, PET, PUR }\end{array}$ & [122] \\
\hline $\begin{array}{l}\text { Deep-sea } \\
\quad \text { fish }\end{array}$ & South China sea $(\mathrm{CN})$ & $\begin{array}{c}1.56 \text { particles } \mathrm{g}^{-1} \text {; } \\
\text { Intestine: } 1.77 \\
\text { particles /individual and } \\
4.89 \text { particles } \mathrm{g}^{-1} \\
0.39\end{array}$ & $<1 \mathrm{~mm}$ & $\mathrm{CPH}, \mathrm{PA}, \mathrm{PET}$, & [138] \\
\hline Indian white shrimps & Kochi, Southwest India (IN) & $\begin{array}{l}\text { particles/individual } \\
0.04 \text { particles }^{-1}\end{array}$ & $0.157-2.785 \mathrm{~mm}$ & PA, PES, PE, PP & [125] \\
\hline \multicolumn{6}{|l|}{ Salt } \\
\hline $\begin{array}{l}\text { Sea salt, lake salt, } \\
\text { rock/well salt }\end{array}$ & China $(\mathrm{CN})$ & $\begin{array}{c}550-681 \text { particles kg }{ }^{-1} \\
\text { (sea salt) } \\
\text { 43-364 particles kg }{ }^{-1} \text { (lake salt) } \\
7-204 \text { particles } \mathrm{kg}^{-1} \text { (rock/well salt) }\end{array}$ & $0.1-1 \mathrm{~mm}$ & $\begin{array}{l}\text { PET, PE, PB, PP, } \\
\text { PES, CPH }\end{array}$ & [170] \\
\hline $\begin{array}{l}\text { Ocean salt, sea salt, rock } \\
\text { salt }\end{array}$ & United States (USA) & $47-806$ particles $\mathrm{kg}^{-1}$ & $0.1-5 \mathrm{~mm}$ & & [166] \\
\hline Sea salt & Italy (IT) & 1600-8200 particles kg ${ }^{-1}$ & $0.004-2.1 \mathrm{~mm}$ & & [168] \\
\hline Sea salt & Croatia & $13,500-19,800$ particles $\mathrm{kg}^{-1}$ & $0.015-4.6 \mathrm{~mm}$ & PP & [168] \\
\hline
\end{tabular}


Table 1. Cont.

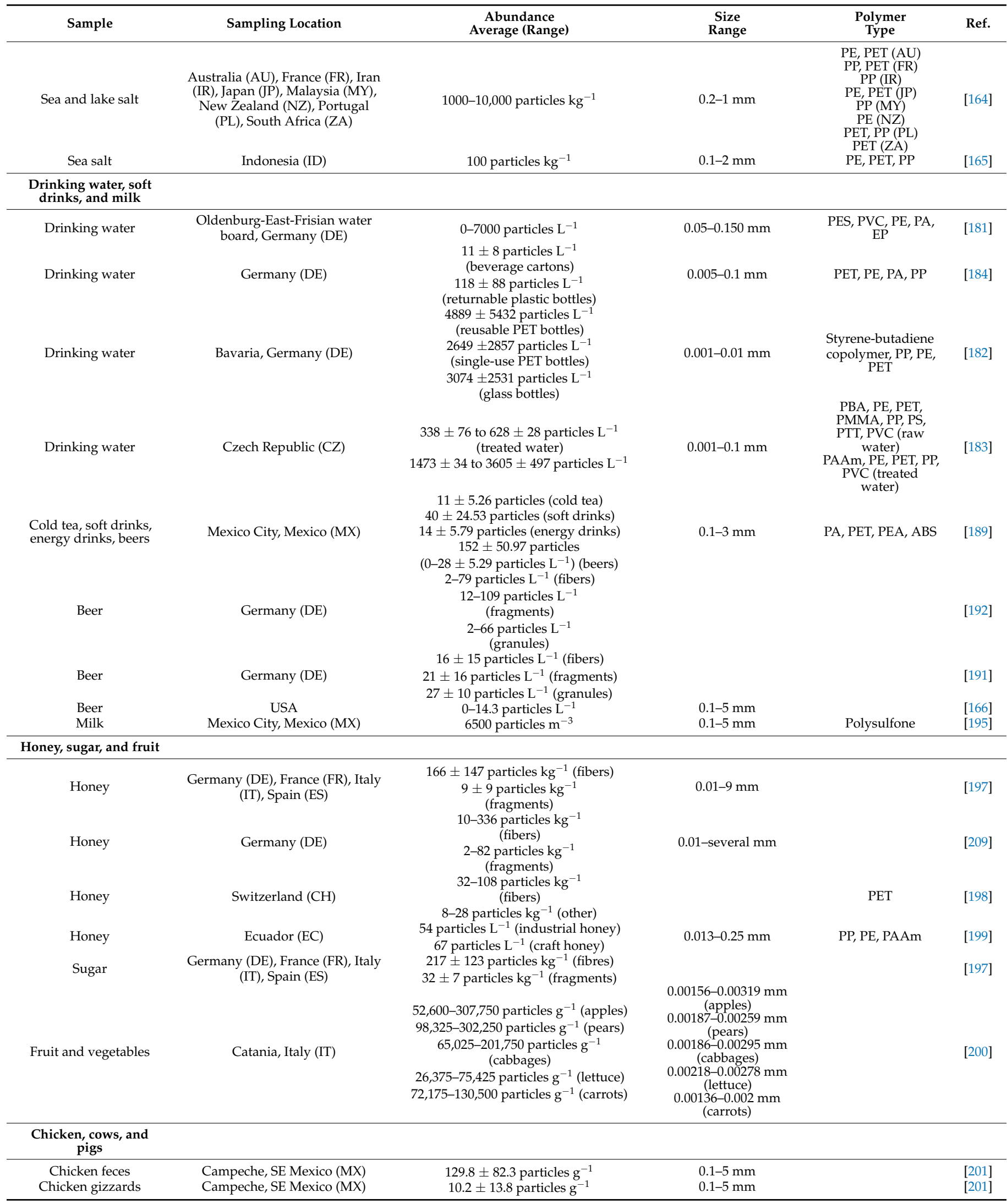


Table 1. Cont.

\begin{tabular}{|c|c|c|c|c|c|}
\hline Sample & Sampling Location & $\begin{array}{c}\text { Abundance } \\
\text { Average (Range) }\end{array}$ & $\begin{array}{c}\text { Size } \\
\text { Range }\end{array}$ & $\begin{array}{l}\text { Polymer } \\
\text { Type }\end{array}$ & Ref. \\
\hline Poultry, pigs, cows & South China $(\mathrm{CN})$ & $\begin{array}{c}902 \pm 1290 \text { particles } \mathrm{kg}^{-1} \\
\text { (pig manure) } \\
667 \pm 990 \text { particles } \mathrm{kg}^{-1} \\
\text { (poultry manure) } \\
74 \pm 129 \text { particles } \mathrm{kg}^{-1} \\
\text { (cow manure) } \\
139 \pm 115 \text { particles kg } \text { (pig feeds) }^{-1} \\
96 \pm 109 \text { particles } \mathrm{kg}^{-1} \\
\text { (poultry feeds) } \\
36 \pm 63 \text { particles } \mathrm{kg}^{-1} \\
\text { (cow feeds) }\end{array}$ & $<5 \mathrm{~mm}$ & PP, PE, PET & [204] \\
\hline
\end{tabular}

Abbreviations. MO: microscope; FTIR: Fourier transform infrared spectroscopy; RMS: Raman spectroscopy; SEM: scanning electron microscope; FTIR-ATR: Fourier transform infrared spectroscopy-attenuated total reflectance; SEM-EDX: scanning electron microscopy with energy dispersive X-ray analysis; PE: polyethylene; PP: polypropylene; PS: polystyrene; PVA: polyvinyl alcohol; PVC: polyvinyl chloride; PES: polyester; PET: polyethylene terephthalate; PUR: polyurethane; PA: polyamide; NY: nylon; CPH: cellophane; RY: rayon; EP: epoxy resin; ALK: alkyd resin; PAN: polyacrylonitrile; PMMA: poly(methyl methacrylate); ABS: acrylonitrile butadiene styrene; PEVA: polyethylene-vinyl acetate; PAAm: polyacrylamide; PB: poly(1-butene); PBA: polybutylacrylate; PTT: polytrimethylene terephthalate; PEA: poly(ester-amide).

Table 2. Estimated intake of microplastics through inhalation, food and beverages, and packaging.

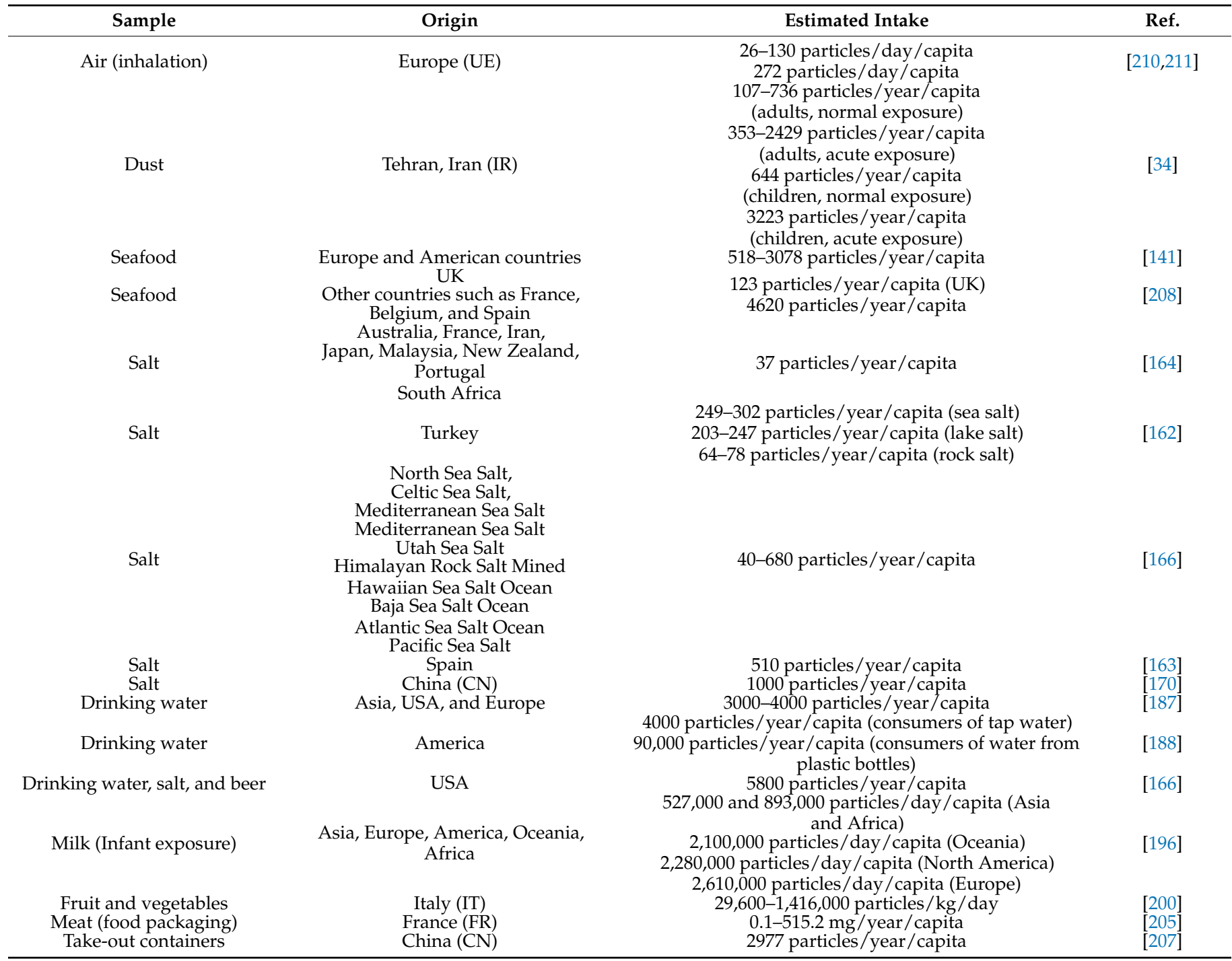


All these studies suggest a not-negligible ingestion of microplastic particles. However, these examples are still too few to be sufficiently representative of true microplastic contamination, so further studies need to be performed in order to have more data on the human ingestion of microplastics from foods different from those related to the water environment. Considering these results, toxicological and epidemiological studies need to be performed to investigate more deeply the possible consequences of microplastics found in foods on human health.

\section{Implication of Microplastic Contamination on Human Health}

\subsection{Possible Routes for Human Exposure to Microplastics}

The human body's exposure to microplastics passes through different routes: ingestion [136,188], inhalation [210], and dermal contact [212] (Figure 2). Each of these routes of exposure is related to a particular environment and its chemical-physical characteristics.

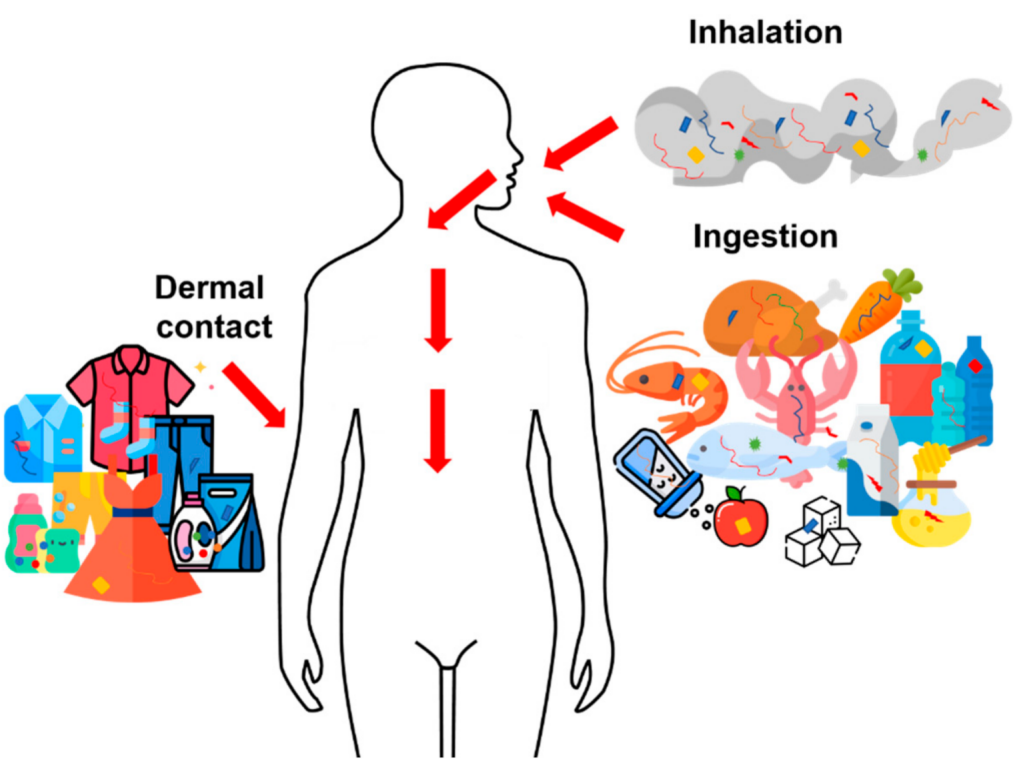

Figure 2. Schematic representation of exposure to microplastics through three routes: ingestion, inhalation, and dermal contact.

In the previous paragraph, we underlined the occurrence and abundance of microplastics in the air and soil web and their transport within the food web, from seafood to beverages and fruits. Considering the high microplastic concentrations detected, the above-mentioned exposure routes can represent important issues for human health.

MPs can have potential adverse effects on human health [210], such as inflammation and secondary genotoxicity [57], and their accumulation can induce or enhance an immune response [111]. Inhaled microplastics can translocate into the respiratory epithelium via diffusion, direct cellular penetration, or active cellular uptake, as reported for other nonbiological micro-and nanoparticles [111]. The preliminary effects of microplastic inhalation were studied in workers involved in plastic processing. Histopathological analysis of the lungs of these workers showed interstitial fibrosis and granulomatous lesions, postulated to be acrylic, polyester, and nylon dust $[213,214]$. The comparison between the number of microplastics absorbed by inhalation and that by ingestion (through the food web) was also reported in the literature [215]. It was observed that the amount of inhaled MPs was from 3 to 15 times higher than the ingested ones, so the levels of MP ingestion by humans are minimal compared to exposure [208].

Dermal contact with microplastics is considered a less significant route of exposure, usually associated with exposure to monomers and additives, such as the endocrine disruptors bisphenol A and phthalates, from the daily use of common appliances [212,216]. For instance, dermal uptake was investigated in rainbow trout. There is evidence for the 
uptake of $1 \mu \mathrm{m}$ latex spheres from the surrounding water, with particles localizing and persisting in the surface and sub-surface epidermal cells of the skin and in phagocytes underlying the gill surface [217]. In humans, surgical sutures in medicine, i.e., braided polyester and polypropylene, are known to induce low inflammatory reactions and a foreign body reaction with fibrous encapsulation. Moreover, human epithelial cells suffer oxidative stress from exposure to microplastics and nanoplastics as well [218].

Persorption is considered as a possible route of uptake in the gastrointestinal tract, and it describes the mechanical kneading of solid particles (up to $130 \mu \mathrm{m}$ diameter) through gaps in the single-layer epithelium at the villus tips and into the circulatory system [219-221]. Samples of persorption were obtained using PVC particles $(5-110 \mu \mathrm{m})$ as a model of nondegradable microparticles, following exposure via feeding or rectal administration, in rats, guinea pigs, rabbits, chickens, dogs, and pigs. Persorption has also been reported in human subjects by using starch particles $(200 \mathrm{~g})$ that led to granules being observed in urine, bile, cerebrospinal fluid, peritoneal fluid, and breast milk [222]. Peyer's patches of the ileum (the third portion of the small intestine) are considered the major sites of uptake and translocation of particles in the gastrointestinal tract. The uptake of plastic microspheres (1-2.2 $\mu \mathrm{m})$ by Peyer's patches has been reported in mammalian models such as rats, with an estimation of $60 \%$ of PS nanoparticle $(60 \mathrm{~nm})$ uptake occurring via Peyer's patches in rats following 5-day oral dosing. The accumulation of MPs in this compartment could interfere with endogenous microparticle uptake and, consequently, immunosensing and surveillance, compromising local immunity [111].

Obviously, a real estimation of the number of microplastics accumulated in the human body is difficult to obtain. Only a few studies have performed human exposure assessments for MPs, considering total intake from different routes [174,188]. In a recent study, a probabilistic model was used to estimate child and adult exposure to MPs and their accumulation during life [223]. The model considered the ingestion of food (fish, salt, mollusks, and crustaceans) and beverages (tap water, bottled water, beer, and milk) and inhalation through the atmosphere as the main routes of exposure to quantify microplastic intake. Moreover, it included intestinal absorption and biliary excretion to assess MP accumulation. The results highlighted a small contribution of microplastics to total chemical intake compared to other more hazardous contaminants with the same exposure routes, e.g., benzo(a)pyrene, di(2-ethylhexyl)phthalate, 3,3' ${ }^{\prime}, 4,4^{\prime}, 5$-pentachlorobiphenyl, and lead.

Notwithstanding the above, human exposure to MPs remains not-negligible, thus warranting investigations on their effects on humans.

\subsection{Toxicological Studies and Consequences to Human Health}

Adverse effects of environmental exposure to MPs have been mostly studied using marine organisms (77\%) and freshwater organisms (23\%), while research involving terrestrial organisms is still in its beginnings [224,225]. Often, aquatic organisms at the start of the trophic web are considered since the plastic contamination of such species has become the main topic in bioaccumulation and biomagnification dynamics [226]. For example, a recent study suggested that aquatic microplastic pollution could affect the growth and feeding behavior of Artemia salina, a planktonic organism used as a primary food source for many farmed species [227]. In particular, brine shrimps easily internalized $10 \mu \mathrm{m}$ polystyrene microspheres through filtration. In the absence of a food source, this phenomenon also occurred at low concentrations $(1 \mathrm{MPs} / \mathrm{mL})$, whereas, in the presence of a food source (Dunaliella salina), microplastics were ingested only at higher concentrations (10-100 MPs/mL). MP uptake, in a dose-dependent manner, caused lower ingestion of a nutritional food source, which led to a developmental delay and a reduction in total body length.

In the last few years, the impact of microplastics and nanoplastics on the human body has been analyzed in both in vitro and in vivo studies [228-231]. The toxicological hazard of microplastic and nanoplastic exposure to humans through oral ingestion was recently assessed [232]. Several toxicological studies on ingested microplastics are reported 
in the literature, most of which used polystyrene particles as a benchmark material for more complex microplastics, while only a few examples regarded polyethylene [233-235]. However, none of the studies considered human exposure to real-life microplastic samples but evaluated the toxicological effects of PS plastic particles on cell cultures [236-238] and also experimental mammal animal models [239-242]. Moreover, the toxic effects strongly depended on the dose, dose rate, and duration of exposure used in the experiments. The majority of studies on polystyrene particles in cell cultures considered short-term exposure to high microplastic concentrations and showed toxicological effects on parameters such as oxidative stress [218,237,238], inflammation [236,243], mitochondrial dysfunction [238], lysosomal dysfunction [244], and apoptosis [243], whereas only a few studies investigated genotoxicity [245-247] (see Figure 3 for the main toxicological effects found in cell cultures).

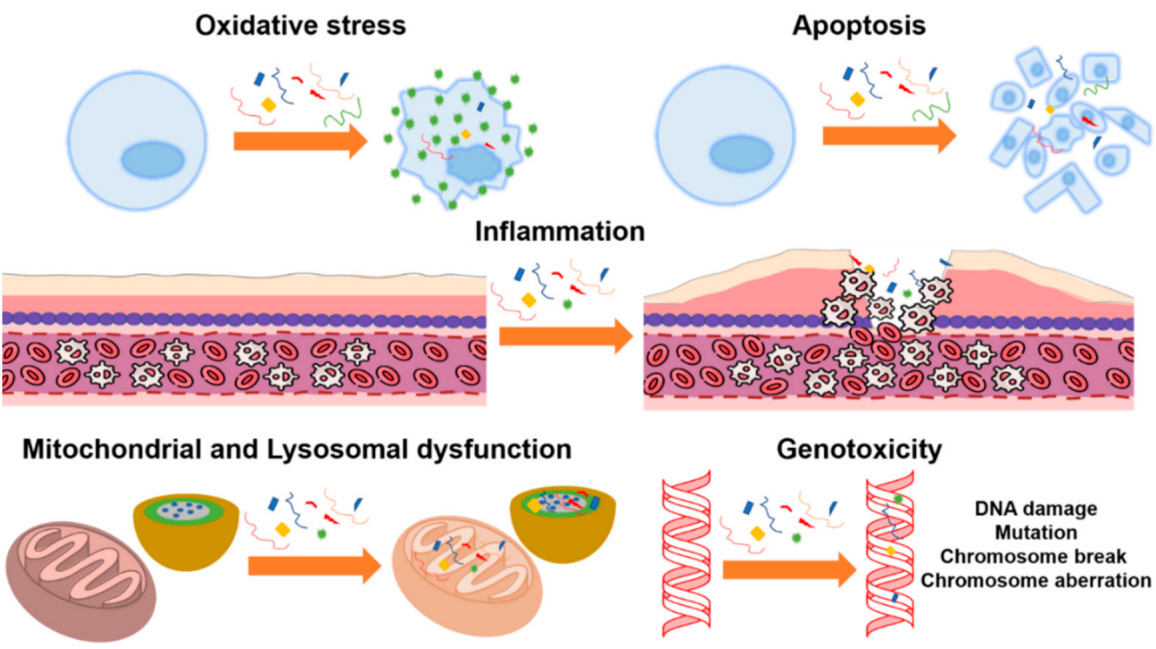

Figure 3. Toxicological effects of polystyrene microparticles on cell cultures: oxidative stress, apoptosis, inflammation, mitochondrial and lysosomal dysfunction, and genotoxicity.

In contrast to these data, obvious indices of toxicity have not been demonstrated in animal models. Concerning particle size, more toxic results are observed for PS particles that are less than $100 \mathrm{~nm}$ with respect to particles larger than $100 \mathrm{~nm}$. Moreover, it was observed that in the functionalization of PS particles, both carboxyl groups (-COOH) and amine groups $\left(-\mathrm{NH}_{2}\right)$ make microparticles more toxic than non-functionalized ones [248]. In the case of polyethylene particles, studies have suggested that these microplastics generate only inflammatory reactions.

Since inhalation is one of the main routes for human exposure to microplastics, some studies have regarded the effects of polystyrene nanoparticles (PS-NPs) on human lung epithelial A549 cells, usually used as a model for human alveolar type II pulmonary epithelium [249-253]. It has been shown that PS-NPs might directly interfere with membrane transporter (P-glycoprotein/MDR1) function in A549 cells, in an amount that depends on their size and surface properties, resulting in a possible influence on the disposition of xenobiotic and endogenous substrates [249]. Moreover, PS-NPs are rapidly internalized by A549 cells, affecting their viability, apoptosis, and cell cycle and disturbing gene transcription and protein expression [250]. The results of this study clearly showed that knowledge of parameters such as the concentration of particles, diameter, and exposure time is necessary to assess the toxicological effects of these particles on human alveolar epithelial A549 cells [250]. Recently, the combined toxicity of PS-NPs and phthalate esters on A549 cells was also investigated. At a greater concentration of PS-NPs, these particles have a dominant role in the combined cytotoxicity observed in mechanisms of oxidative stress and inflammatory reactions [251]. Moreover, to evaluate the potential toxicological effects of microplastics, A549 cells were exposed to polystyrene microplastics. The inhibition of cell proliferation and major changes in cell morphology were observed, confirming that microplastics have a potential for harm to humans [253]. 
Moreover, A549 cells were used to assess the toxicity of polyvinyl chloride (PVC) microparticles since the inhalation of PVC dust has been associated with pulmonary diseases [254,255]. PVC microparticles produced in vitro cytotoxicity and inflammatory potential for several rat and human pulmonary cells, perhaps due to the presence of residual additives [254,255].

Considering ingestion as another important exposure route for humans, the interaction of PS-NPs with human intestinal cells and intestinal translocation was studied using different in vitro models $[256,257]$. No significant cytotoxic effect and no adverse effects in the integrity or permeability of the barrier mode were detected [256]. Nevertheless, the studies confirmed the capability of particles to cross the epithelial barrier of the digestive system, which should not be underestimated because of other possible long-term implications [257]. Factors affecting the cellular uptake of PS-NPs were also investigated in different cell lines [258-260]. Experiments performed using carboxylated PS-NPs (40 and $200 \mathrm{~nm}$ of diameter) revealed that NPs enter cells via active energy-dependent processes for all cell types but exploit different uptake mechanisms depending on cell type [258]. Moreover, surface charge is the main parameter influencing cellular uptake efficiency, whereas compositional elements, aggregation/agglomeration, and protein corona formation results are less relevant [259].

As previously mentioned, MPs can adsorb chemicals such as heavy metals, persistent organic pollutants plasticizers [261], antioxidants and slip agents [262], and some potential pathogens [26-28] on their surface, increasing the exposure of humans to toxic chemicals and additives. For example, high concentrations of phthalates and organophosphorus esters have been detected on some beached microplastics based on PP flakes and PS foams [21]. Moreover, MPs containing high levels of potentially bioavailable toxic substances (e.g., lead, cadmium, organochlorine compounds, copper, zinc, and hydrocarbons) may represent a significant ecotoxicological risk for the early life stages of aquatic organisms [263]. As a catalytic surface, microplastics can also affect biochemical processes in organisms, increasing intakes and accumulations of pollutants in organisms [239]. It has been documented how aged plastics strengthen their ability to absorb chemicals because of weathering. Some studies have shown the bioaccumulation of chemicals from plastics in organisms [58] and the presence of potentially pathogenic bacteria on microplastics [27]. Furthermore, biofilm communities on microplastics from three marine ecosystems (the Baltic, Sargasso, and Mediterranean seas) were characterized using high-throughput $16 \mathrm{~S}$ rRNA gene sequencing. As a result of this investigation, MPs were found to be a possible reservoir of rare and understudied microbes, hence encouraging future studies in this field [28]. MPs colonized by potential pathogens showed a close relationship with coral diseases, with the possibility of disease $4-89 \%$ greater than a plastic-free condition [264]. Increased exposure to microplastics can cause immune disorders, neurodegenerative diseases, and cancer $[212,265]$.

Another important issue arises from the ability of microplastics to accumulate over time and to be bio-persistent [111]. An artificial in vitro digestion protocol (considering the three digestive compartments: mouth, stomach, and intestine) allowed us to analyze the effects of gastrointestinal passage on the physiochemical particle characteristics of the most environmentally abundant materials, such as PE, PP; PVC, PET, and PS [266]. The SEM results demonstrated a high resistance of all MPs to the artificial digestive juices compared to the influence of the positive controls of hydrochloric acid, nitric acid, and acetone. Moreover, a cross-disciplinary review discusses and evaluates the potential impacts of microplastics on human health through diet and environment [111]. There was no evidence of increased cancer risk for nylon flock workers, although they had a higher prevalence of respiratory diseases (dyspnea, coughing, reduced lung capacity, and wheezing) [267-269].

Ultimately, several toxic effects of plastic particles were observed, but they mainly occurred for particle sizes smaller than $5 \mu \mathrm{m}$ at a concentration much higher than human exposure, demonstrating hazard rather than risk for human health, so the same effects at low concentration must be verified. Epidemiological studies must be carried out to 
assess the real consequence of microplastic contamination at concentrations in the range of human exposure.

\subsection{Future Trends: Occurrence in Body Fluids and Related Effects}

The above-discussed papers assert an elevated microplastics intake, so a deeper investigation on the translocation and accumulation of MPs in the human body is needed to better characterize their potential to harm humans. In fact, MP occurrence and detection in the fluids of the human body remain a poorly investigated field but could be very useful for assessing the interaction of plastic particles with the human body.

In a recent study, the presence of microplastics in human stool was investigated [270]. All samples analyzed (from 3 men and 5 women) contained microplastics (size range of $50-500 \mu \mathrm{m}$ ), with polypropylene and polyethylene terephthalate as the most abundant polymers and an average concentration of 2 particles/g of fecal matter.

Surprisingly, microplastic fragments were also detected in human placenta samples collected from six consenting women with uneventful pregnancies [271]. Analysis by Raman microspectroscopy was able to detect 12 pigmented microplastic fragments (5-10 $\mu \mathrm{m}$ in size) in 4 placentas, mainly polypropylene. The presence of microplastics in the human placenta is a matter of great concern, so further studies should be performed to evaluate if it can result in harmful effects on pregnancy.

These results encourage the search for microplastics in human fluids, and other investigations should be carried out to assess how microplastics interact with the human body and reach its fluids. A significant issue to consider in microplastic determination is the contamination of samples due to airborne microplastics. Consequently, great attention must be paid to sample treatment to avoid the misidentification of microplastics in human samples, especially for low size particles $(<10 \mathrm{~mm})$, and enlarge the number of samples collected. Therefore, in the near future, new methodologies should be developed to count and characterize MPs in body fluids, avoiding interferences as much as possible.

Moreover, more international and cross-disciplinary research focusing on the toxicology of these particles is urgently needed to fully understand the long-term effects on humans and help health organizations to provide prevention guidelines.

\section{Conclusions}

Plastic microparticle accumulation in the environment leads to stress on ecosystems. In this review, we analyzed the most recent literature related to microplastics in the environment and food, the potential route of exposure for humans, and toxicological effects. We have underlined how several literature studies have detected high microplastic concentrations in the environment, with the consequent transport of these particles within the food web, from seafood to beverages and fruits. A higher number of studies have researched the contamination of sea products, drinking water (raw, treated, and stored in different packages), salts for human consumption, and honey, sugar, fruit, and chickens. All these studies suggest a not-negligible ingestion of microplastic particles through food consumption. Several toxic effects of ingested microplastics, mainly PS, were reported to occur at high microplastic concentrations compared to human exposure, demonstrating a hazard for human health. Further studies must be performed to assess the real consequences of microplastic contamination at concentrations in the range of human exposure. Increasing awareness of the potential and growing risks to human health has not been accompanied by considerable efforts to establish the influence of microplastic abundance on human health in vivo, most probably because of the lack of standardization of sampling methodologies and the separation of MPs. This review aims to guide future researchers into a deeper investigation of the processes involved in MP uptake, the potential mechanisms of toxicity, and health effects. 
Author Contributions: Conceptualization: O.M., A.P. and L.M. Data curation: C.P. and M.R. Formal analysis: C.P. and M.R. Funding acquisition: O.M. and A.P. Investigation: C.P., M.R. and Y.M. Methodology: C.P., M.R. and Y.M. Project administration and resources: O.M. and A.P. Software: C.P., M.R. and Y.M. Supervision and validation: O.M., A.P. and L.M. Visualization: C.P., M.R., Y.M., O.M. and A.P. Writing original draft: C.P. and M.R. Writing-review and editing: O.M. and L.M. All authors have read and agreed to the published version of the manuscript.

Funding: This work was financially supported by Fondi di Ateneo per la Ricerca di Base "FARB 2020", University of Salerno.

Institutional Review Board Statement: Not applicable.

Informed Consent Statement: Not applicable.

Data Availability Statement: No new data were created or analyzed in this study. Data sharing is not applicable to this article.

Acknowledgments: The authors gratefully acknowledge Antonio Faggiano for graphics support.

Conflicts of Interest: The authors declare no conflict of interest.

\section{References}

1. Sadri, S.S.; Thompson, R.C. On the Quantity and Composition of Floating Plastic Debris Entering and Leaving the Tamar Estuary, Southwest England. Mar. Pollut. Bull. 2014, 81, 55-60. [CrossRef]

2. Cole, M.; Lindeque, P.; Halsband, C.; Galloway, T.S. Microplastics as Contaminants in the Marine Environment: A Review. Mar. Pollut. Bull. 2011, 62, 2588-2597. [CrossRef]

3. Hale, R.C.; Seeley, M.E.; la Guardia, M.J.; Mai, L.; Zeng, E.Y. A Global Perspective on Microplastics. J. Geophys. Res. Oceans 2020, 125. [CrossRef]

4. Wright, S.L.; Thompson, R.C.; Galloway, T.S. The Physical Impacts of Microplastics on Marine Organisms: A Review. Environ. Pollut. 2013, 178, 483-492. [CrossRef]

5. Gaylarde, C.C.; Neto, J.A.B.; da Fonseca, E.M. Paint Fragments as Polluting Microplastics: A Brief Review. Mar. Pollut. Bull. 2021, 162, 111847. [CrossRef]

6. Motta, O.; Proto, A.; de Carlo, F.; de Caro, F.; Santoro, E.; Brunetti, L.; Capunzo, M. Utilization of Chemically Oxidized Polystyrene as Co-Substrate by Filamentous Fungi. Int. J. Hyg. Environ. Health 2009, 212, 61-66. [CrossRef]

7. Hidalgo-Ruz, V.; Gutow, L.; Thompson, R.C.; Thiel, M. Microplastics in the Marine Environment: A Review of the Methods Used for Identification and Quantification. Environ. Sci. Technol. 2012, 46, 3060-3075. [CrossRef] [PubMed]

8. Zhang, K.; Hamidian, A.H.; Tubić, A.; Zhang, Y.; Fang, J.K.H.; Wu, C.; Lam, P.K.S. Understanding Plastic Degradation and Microplastic Formation in the Environment: A Review. Environ. Pollut. 2021, 274, 116554. [CrossRef]

9. Qi, R.; Jones, D.L.; Li, Z.; Liu, Q.; Yan, C. Behavior of Microplastics and Plastic Film Residues in the Soil Environment: A Critical Review. Sci. Total Environ. 2020, 703, 134722. [CrossRef]

10. Kuhn, D.A.; Vanhecke, D.; Michen, B.; Blank, F.; Gehr, P.; Petri-Fink, A.; Rothen-Rutishauser, B. Different Endocytotic Uptake Mechanisms for Nanoparticles in Epithelial Cells and Macrophages. Beilstein J. Nanotechnol. 2014, 5, 1625-1636. [CrossRef]

11. Ma, N.; Ma, C.; Li, C.; Wang, T.; Tang, Y.; Wang, H.; Mou, X.; Chen, Z.; He, N. Influence of Nanoparticle Shape, Size, and Surface Functionalization on Cellular Uptake. J. Nanosci. Nanotech. 2013, 13, 6485-6498. [CrossRef]

12. Gray, A.D.; Weinstein, J.E. Size- and Shape-Dependent Effects of Microplastic Particles on Adult Daggerblade Grass Shrimp (Palaemonetes Pugio). Environ. Toxicol. Chem. 2017, 36, 3074-3080. [CrossRef]

13. Savoca, S.; Capillo, G.; Mancuso, M.; Faggio, C.; Panarello, G.; Crupi, R.; Bonsignore, M.; D’Urso, L.; Compagnini, G.; Neri, F.; et al. Detection of Artificial Cellulose Microfibers in Boops Boops from the Northern Coasts of Sicily (Central Mediterranean). Sci. Total Environ. 2019, 691, 455-465. [CrossRef]

14. Woodall, L.C.; Sanchez-Vidal, A.; Canals, M.; Paterson, G.L.J.; Coppock, R.; Sleight, V.; Calafat, A.; Rogers, A.D.; Narayanaswamy, B.E.; Thompson, R.C. The Deep Sea Is a Major Sink for Microplastic Debris. R. Soc. Open Sci. 2014, 1, 140317. [CrossRef] [PubMed]

15. Remy, F.; Collard, F.; Gilbert, B.; Compère, P.; Eppe, G.; Lepoint, G. When Microplastic Is Not Plastic: The Ingestion of Artificial Cellulose Fibers by Macrofauna Living in Seagrass Macrophytodetritus. Environ. Sci. Technol. 2015, 49, 11158-11166. [CrossRef]

16. Collard, F.; Gilbert, B.; Eppe, G.; Parmentier, E.; Das, K. Detection of Anthropogenic Particles in Fish Stomachs: An Isolation Method Adapted to Identification by Raman Spectroscopy. Arch. Environ. Contam. Toxicol. 2015, 69, 331-339. [CrossRef]

17. Ammala, A.; Bateman, S.; Dean, K.; Petinakis, E.; Sangwan, P.; Wong, S.; Yuan, Q.; Yu, L.; Patrick, C.; Leong, K.H. An Overview of Degradable and Biodegradable Polyolefins. Prog. Polym. Sci. 2011, 36, 1015-1049. [CrossRef]

18. Liu, P.; Zhan, X.; Wu, X.; Li, J.; Wang, H.; Gao, S. Effect of Weathering on Environmental Behavior of Microplastics: Properties, Sorption and Potential Risks. Chemosphere 2020, 242, 125193. [CrossRef]

19. Romera-Castillo, C.; Pinto, M.; Langer, T.M.; Álvarez-Salgado, X.A.; Herndl, G.J. Dissolved Organic Carbon Leaching from Plastics Stimulates Microbial Activity in the Ocean. Nat. Commun. 2018, 9, 1430. [CrossRef] 
20. Liu, X.; Shi, H.; Xie, B.; Dionysiou, D.D.; Zhao, Y. Microplastics as Both a Sink and a Source of Bisphenol A in the Marine Environment. Environ. Sci. Technol. 2019, 53, 10188-10196. [CrossRef]

21. Zhang, H.; Zhou, Q.; Xie, Z.; Zhou, Y.; Tu, C.; Fu, C.; Mi, W.; Ebinghaus, R.; Christie, P.; Luo, Y. Occurrences of Organophosphorus Esters and Phthalates in the Microplastics from the Coastal Beaches in North China. Sci. Total Environ. 2018, 616-617, 1505-1512. [CrossRef]

22. Barboza, L.G.A.; Cunha, S.C.; Monteiro, C.; Fernandes, J.O.; Guilhermino, L. Bisphenol A and Its Analogs in Muscle and Liver of Fish from the North East Atlantic Ocean in Relation to Microplastic Contamination. Exposure and Risk to Human Consumers. J. Hazard. Mater. 2020, 393, 122419. [CrossRef]

23. Pironti, C.; Ricciardi, M.; Proto, A.; Bianco, P.M.; Montano, L.; Motta, O. Endocrine-Disrupting Compounds: An Overview on Their Occurrence in the Aquatic Environment and Human Exposure. Water 2021, 13, 1347. [CrossRef]

24. Deng, Y.; Yan, Z.; Shen, R.; Huang, Y.; Ren, H.; Zhang, Y. Enhanced Reproductive Toxicities Induced by Phthalates Contaminated Microplastics in Male Mice (Mus Musculus). J. Hazard. Mater. 2021, 406, 124644. [CrossRef]

25. Caruso, G. Microplastics as Vectors of Contaminants. Mar. Pollut. Bull. 2019, 146, 921-924. [CrossRef]

26. Jiang, P.; Zhao, S.; Zhu, L.; Li, D. Microplastic-Associated Bacterial Assemblages in the Intertidal Zone of the Yangtze Estuary. Sci. Total Environ. 2018, 624, 48-54. [CrossRef]

27. Kirstein, I.V.; Kirmizi, S.; Wichels, A.; Garin-Fernandez, A.; Erler, R.; Löder, M.; Gerdts, G. Dangerous Hitchhikers? Evidence for Potentially Pathogenic Vibrio Spp. on Microplastic Particles. Mar. Environ. Res. 2016, 120, 1-8. [CrossRef]

28. Scales, B.S.; Cable, R.N.; Duhaime, M.B.; Gerdts, G.; Fischer, F.; Fischer, D.; Mothes, S.; Hintzki, L.; Moldaenke, L.; Ruwe, M.; et al. Cross-Hemisphere Study Reveals Geographically Ubiquitous, Plastic-Specific Bacteria Emerging from the Rare and Unexplored Biosphere. mSphere 2021, 6, e0085120. [CrossRef] [PubMed]

29. Rodrigues, J.P.; Duarte, A.C.; Santos-Echeandía, J.; Rocha-Santos, T. Significance of Interactions between Microplastics and POPs in the Marine Environment: A Critical Overview. Trends Anal. Chem. 2019, 111, 252-260. [CrossRef]

30. Squadrone, S.; Pederiva, S.; Bezzo, T.; Sartor, R.M.; Battuello, M.; Nurra, N.; Griglione, A.; Brizio, P.; Abete, M.C. Microplastics as Vectors of Metals Contamination in Mediterranean Sea. Environ. Sci. Pollut. Res. 2021. [CrossRef]

31. Ashton, K.; Holmes, L.; Turner, A. Association of Metals with Plastic Production Pellets in the Marine Environment. Mar. Pollut. Bull. 2010, 60, 2050-2055. [CrossRef]

32. Holmes, L.A.; Turner, A.; Thompson, R.C. Adsorption of Trace Metals to Plastic Resin Pellets in the Marine Environment. Environ. Pollut. 2012, 160, 42-48. [CrossRef] [PubMed]

33. Vedolin, M.C.; Teophilo, C.Y.S.; Turra, A.; Figueira, R.C.L. Spatial Variability in the Concentrations of Metals in Beached Microplastics. Mar. Pollut. Bull. 2018, 129, 487-493. [CrossRef] [PubMed]

34. Dehghani, S.; Moore, F.; Akhbarizadeh, R. Microplastic Pollution in Deposited Urban Dust, Tehran Metropolis, Iran. Environ. Sci. Pollut. Res. 2017, 24, 20360-20371. [CrossRef]

35. Carpenter, E.J.; Smith, K.L. Plastics on the Sargasso Sea Surface. Science 1972, 175, 1240-1241. [CrossRef]

36. Carpenter, E.J.; Anderson, S.J.; Harvey, G.R.; Miklas, H.P.; Peck, B.B. Polystyrene Spherules in Coastal Waters. Science 1972, 178, 749-750. [CrossRef]

37. Colton, J.B.; Burns, B.R.; Knapp, F.D. Plastic Particles in Surface Waters of the Northwestern Atlantic. Science 1974, 185, 491-497. [CrossRef]

38. Wong, C.S.; Green, D.R.; Cretney, W.J. Quantitative Tar and Plastic Waste Distributions in the Pacific Ocean. Nature 1974, 247, 30-32. [CrossRef]

39. Eerkes-Medrano, D.; Thompson, R.C.; Aldridge, D.C. Microplastics in Freshwater Systems: A Review of the Emerging Threats, Identification of Knowledge Gaps and Prioritisation of Research Needs. Water Res. 2015, 75, 63-82. [CrossRef] [PubMed]

40. Prata, J.C. Microplastics in Wastewater: State of the Knowledge on Sources, Fate and Solutions. Mar. Pollut. Bull. 2018, 129, 262-265. [CrossRef]

41. Enfrin, M.; Dumée, L.F.; Lee, J. Nano/Microplastics in Water and Wastewater Treatment Processes-Origin, Impact and Potential Solutions. Water Res. 2019, 161, 621-638. [CrossRef]

42. Wong, J.K.H.; Lee, K.K.; Tang, K.H.D.; Yap, P.-S. Microplastics in the Freshwater and Terrestrial Environments: Prevalence, Fates, Impacts and Sustainable Solutions. Sci. Total Environ. 2020, 719, 137512. [CrossRef] [PubMed]

43. Li, C.; Busquets, R.; Campos, L.C. Assessment of Microplastics in Freshwater Systems: A Review. Sci. Total Environ. 2020, 707, 135578. [CrossRef]

44. Akdogan, Z.; Guven, B. Microplastics in the Environment: A Critical Review of Current Understanding and Identification of Future Research Needs. Environ. Pollut. 2019, 254, 113011. [CrossRef]

45. Wu, P.; Huang, J.; Zheng, Y.; Yang, Y.; Zhang, Y.; He, F.; Chen, H.; Quan, G.; Yan, J.; Li, T.; et al. Environmental Occurrences, Fate, and Impacts of Microplastics. Ecotoxicol. Environ. Saf. 2019, 184, 109612. [CrossRef]

46. Wu, M.; Yang, C.; Du, C.; Liu, H. Microplastics in Waters and Soils: Occurrence, Analytical Methods and Ecotoxicological Effects. Ecotoxicol. Environ. Saf. 2020, 202, 110910. [CrossRef]

47. Ma, H.; Pu, S.; Liu, S.; Bai, Y.; Mandal, S.; Xing, B. Microplastics in Aquatic Environments: Toxicity to Trigger Ecological Consequences. Environ. Pollut. 2020, 261, 114089. [CrossRef] 
48. Sharifinia, M.; Bahmanbeigloo, Z.A.; Keshavarzifard, M.; Khanjani, M.H.; Lyons, B.P. Microplastic Pollution as a Grand Challenge in Marine Research: A Closer Look at Their Adverse Impacts on the Immune and Reproductive Systems. Ecotoxicol. Environ. Saf. 2020, 204, 111109. [CrossRef]

49. Patil, S.; Bafana, A.; Naoghare, P.K.; Krishnamurthi, K.; Sivanesan, S. Environmental Prevalence, Fate, Impacts, and Mitigation of Microplastics-A Critical Review on Present Understanding and Future Research Scope. Environ. Sci. Pollut. Res. 2021, 28, 4951-4974. [CrossRef]

50. Koelmans, A.A.; Besseling, E.; Shim, W.J. Nanoplastics in the aquatic environment. Critical review. In Marine Anthropogenic Litter; Bergmann, M., Gutow, L., Klages, M., Eds.; Springer International Publishing: Berlin/Heidelberg, Germany, 2015; pp. 325-340, ISBN 978-3-319-16510-3.

51. Andrady, A.L. The Plastic in Microplastics: A Review. Mar. Pollut. Bull. 2017, 119, 12-22. [CrossRef] [PubMed]

52. Ricciardi, M.; Pironti, C.; Motta, O.; Miele, Y.; Proto, A.; Montano, L. Microplastics in the Aquatic Environment: Occurrence, Persistence, Analysis, and Human Exposure. Water 2021, 13, 973. [CrossRef]

53. Li, W.C.; Tse, H.F.; Fok, L. Plastic Waste in the Marine Environment: A Review of Sources, Occurrence and Effects. Sci. Total Environ. 2016, 566-567, 333-349. [CrossRef]

54. Al-Salem, S.M.; Uddin, S.; Lyons, B. Evidence of Microplastics (MP) in Gut Content of Major Consumed Marine Fish Species in the State of Kuwait (of the Arabian/Persian Gulf). Mar. Pollut. Bull. 2020, 154, 111052. [CrossRef]

55. Amato-Lourenço, L.F.; dos Santos Galvão, L.; de Weger, L.A.; Hiemstra, P.S.; Vijver, M.G.; Mauad, T. An Emerging Class of Air Pollutants: Potential Effects of Microplastics to Respiratory Human Health? Sci. Total Environ. 2020, 749, 141676. [CrossRef]

56. Chen, G.; Feng, Q.; Wang, J. Mini-Review of Microplastics in the Atmosphere and Their Risks to Humans. Sci. Total Environ. 2020, 703, 135504. [CrossRef]

57. Gasperi, J.; Wright, S.L.; Dris, R.; Collard, F.; Mandin, C.; Guerrouache, M.; Langlois, V.; Kelly, F.J.; Tassin, B. Microplastics in Air: Are We Breathing It in? Curr. Opin. Environ. Sci. Health 2018, 1, 1-5. [CrossRef]

58. Rochman, C.M.; Brookson, C.; Bikker, J.; Djuric, N.; Earn, A.; Bucci, K.; Athey, S.; Huntington, A.; Mcllwraith, H.; Munno, K.; et al. Rethinking Microplastics as a Diverse Contaminant Suite. Environ. Toxicol. Chem. 2019, 38, 703-711. [CrossRef] [PubMed]

59. Tourinho, P.S.; Kočí, V.; Loureiro, S.; van Gestel, C.A.M. Partitioning of Chemical Contaminants to Microplastics: Sorption Mechanisms, Environmental Distribution and Effects on Toxicity and Bioaccumulation. Environ. Pollut. 2019, 252, 1246-1256. [CrossRef] [PubMed]

60. Cucciniello, R.; Proto, A.; la Femina, R.; Pironti, C.; Farina, A.; Motta, O. A New Sorbent Tube for Atmospheric NOx Determination by Active Sampling. Talanta 2017, 164, 403-406. [CrossRef]

61. Cucciniello, R.; Proto, A.; Rossi, F.; Motta, O. Mayenite Based Supports for Atmospheric NOx Sampling. Atmos. Environ. 2013, 79, 666-671. [CrossRef]

62. Motta, O.; Cucciniello, R.; la Femina, R.; Pironti, C.; Proto, A. Development of a New Radial Passive Sampling Device for Atmospheric NOx Determination. Talanta 2018, 190, 199-203. [CrossRef]

63. Li, L.; Moore, P.K. Putative Biological Roles of Hydrogen Sulfide in Health and Disease: A Breath of Not so Fresh Air? Trends Pharmacol. Sci. 2008, 29, 84-90. [CrossRef]

64. Motta, O.; Cucciniello, R.; Scicali, C.; Proto, A. A Study on the Applicability of Zinc Acetate Impregnated Silica Substrate in the Collection of Hydrogen Sulfide by Active Sampling. Talanta 2014, 128, 268-272. [CrossRef]

65. Chen, T.-M.; Kuschner, W.G.; Gokhale, J.; Shofer, S. Outdoor Air Pollution: Nitrogen Dioxide, Sulfur Dioxide, and Carbon Monoxide Health Effects. Am. J. Med. Sci. 2007, 333, 249-256. [CrossRef]

66. Cucciniello, R.; Proto, A.; Alfano, D.; Motta, O. Synthesis, Characterization and Field Evaluation of a New Calcium-Based CO 2 Absorbent for Radial Diffusive Sampler. Atmos. Environ. 2012, 60, 82-87. [CrossRef]

67. El-Shahawi, M.S.; Hamza, A.; Bashammakh, A.S.; Al-Saggaf, W.T. An Overview on the Accumulation, Distribution, Transformations, Toxicity and Analytical Methods for the Monitoring of Persistent Organic Pollutants. Talanta 2010, 80, $1587-1597$. [CrossRef]

68. Carlsen, L.; Bruggemann, R.; Kenessov, B. Use of Partial Order in Environmental Pollution Studies Demonstrated by Urban BTEX Air Pollution in 20 Major Cities Worldwide. Sci. Total Environ. 2018, 610-611, 234-243. [CrossRef] [PubMed]

69. Cucciniello, R.; Proto, A.; Rossi, F.; Marchettini, N.; Motta, O. An Improved Method for BTEX Extraction from Charcoal. Anal. Methods 2015, 7, 4811-4815. [CrossRef]

70. Ambrosini, R.; Azzoni, R.S.; Pittino, F.; Diolaiuti, G.; Franzetti, A.; Parolini, M. First Evidence of Microplastic Contamination in the Supraglacial Debris of an Alpine Glacier. Environ. Pollut. 2019, 253, 297-301. [CrossRef]

71. Liu, K.; Wang, X.; Wei, N.; Song, Z.; Li, D. Accurate Quantification and Transport Estimation of Suspended Atmospheric Microplastics in Megacities: Implications for Human Health. Environ. Int. 2019, 132, 105127. [CrossRef]

72. Wang, X.; Li, C.; Liu, K.; Zhu, L.; Song, Z.; Li, D. Atmospheric Microplastic over the South China Sea and East Indian Ocean: Abundance, Distribution and Source. J. Hazard. Mater. 2020, 389, 121846. [CrossRef]

73. Zhang, Y.; Gao, T.; Kang, S.; Sillanpää, M. Importance of Atmospheric Transport for Microplastics Deposited in Remote Areas. Environ. Pollut. 2019, 254, 112953. [CrossRef]

74. Ballent, A.; Purser, A.; de Jesus Mendes, P.; Pando, S.; Thomsen, L. Physical Transport Properties of Marine Microplastic Pollution. Biogeosci. Discuss. 2012, 9, 18755-18798. [CrossRef] 
75. Eriksson, C.; Burton, H.; Fitch, S.; Schulz, M.; van den Hoff, J. Daily Accumulation Rates of Marine Debris on Sub-Antarctic Island Beaches. Mar. Pollut. Bull. 2013, 66, 199-208. [CrossRef]

76. Barnes, D.K.A.; Galgani, F.; Thompson, R.C.; Barlaz, M. Accumulation and Fragmentation of Plastic Debris in Global Environments. Philos. Trans. R. Soc. B 2009, 364, 1985-1998. [CrossRef]

77. Martinez, E.; Maamaatuaiahutapu, K.; Taillandier, V. Floating Marine Debris Surface Drift: Convergence and Accumulation toward the South Pacific Subtropical Gyre. Mar. Pollut. Bull. 2009, 58, 1347-1355. [CrossRef] [PubMed]

78. Dris, R.; Gasperi, J.; Rocher, V.; Saad, M.; Renault, N.; Tassin, B. Microplastic Contamination in an Urban Area: A Case Study in Greater Paris. Environ. Chem. 2015, 12, 592-599. [CrossRef]

79. Ryan, P.G.; Moore, C.J.; van Franeker, J.A.; Moloney, C.L. Monitoring the Abundance of Plastic Debris in the Marine Environment. Philos. Trans. R. Soc. B 2009, 364, 1999-2012. [CrossRef]

80. Doyle, M.J.; Watson, W.; Bowlin, N.M.; Sheavly, S.B. Plastic Particles in Coastal Pelagic Ecosystems of the Northeast Pacific Ocean. Mar. Environ. Res. 2011, 71, 41-52. [CrossRef]

81. Horton, A.A.; Walton, A.; Spurgeon, D.J.; Lahive, E.; Svendsen, C. Microplastics in Freshwater and Terrestrial Environments: Evaluating the Current Understanding to Identify the Knowledge Gaps and Future Research Priorities. Sci. Total Environ. 2017, 586, 127-141. [CrossRef] [PubMed]

82. Nizzetto, L.; Bussi, G.; Futter, M.N.; Butterfield, D.; Whitehead, P.G. A Theoretical Assessment of Microplastic Transport in River Catchments and Their Retention by Soils and River Sediments. Environ. Sci. Process. Impacts 2016, 18, 1050-1059. [CrossRef] [PubMed]

83. Van Sebille, E.; Wilcox, C.; Lebreton, L.; Maximenko, N.; Hardesty, B.D.; van Franeker, J.A.; Eriksen, M.; Siegel, D.; Galgani, F.; Law, K.L. A Global Inventory of Small Floating Plastic Debris. Environ. Res. Lett. 2015, 10, 124006. [CrossRef]

84. Kumar, M.; Xiong, X.; He, M.; Tsang, D.C.W.; Gupta, J.; Khan, E.; Harrad, S.; Hou, D.; Ok, Y.S.; Bolan, N.S. Microplastics as Pollutants in Agricultural Soils. Environ. Pollut. 2020, 265, 114980. [CrossRef]

85. Wanner, P. Plastic in Agricultural Soils-A Global Risk for Groundwater Systems and Drinking Water Supplies?-A Review. Chemosphere 2021, 264, 128453. [CrossRef] [PubMed]

86. Rillig, M.C. Microplastic in Terrestrial Ecosystems and the Soil? Environ. Sci. Technol. 2012, 46, 6453-6454. [CrossRef]

87. Scheurer, M.; Bigalke, M. Microplastics in Swiss Floodplain Soils. Environ. Sci. Technol. 2018, 52, 3591-3598. [CrossRef]

88. Bläsing, M.; Amelung, W. Plastics in Soil: Analytical Methods and Possible Sources. Sci. Total Environ. 2018, 612, 422-435. [CrossRef]

89. Hurley, R.R.; Nizzetto, L. Fate and Occurrence of Micro(Nano)Plastics in Soils: Knowledge Gaps and Possible Risks. Curr. Opin. Environ. Sci. Health 2018, 1, 6-11. [CrossRef]

90. Liu, M.; Lu, S.; Song, Y.; Lei, L.; Hu, J.; Lv, W.; Zhou, W.; Cao, C.; Shi, H.; Yang, X.; et al. Microplastic and Mesoplastic Pollution in Farmland Soils in Suburbs of Shanghai, China. Environ. Pollut. 2018, 242, 855-862. [CrossRef]

91. Nizzetto, L.; Futter, M.; Langaas, S. Are Agricultural Soils Dumps for Microplastics of Urban Origin? Environ. Sci. Technol. 2016, 50, 10777-10779. [CrossRef]

92. Talvitie, J.; Mikola, A.; Setälä, O.; Heinonen, M.; Koistinen, A. How Well Is Microlitter Purified from Wastewater?—A Detailed Study on the Stepwise Removal of Microlitter in a Tertiary Level Wastewater Treatment Plant. Water Res. 2017, 109, 164-172. [CrossRef]

93. Allen, S.; Allen, D.; Phoenix, V.R.; le Roux, G.; Durántez Jiménez, P.; Simonneau, A.; Binet, S.; Galop, D. Atmospheric Transport and Deposition of Microplastics in a Remote Mountain Catchment. Nature Geosci. 2019, 12, 339-344. [CrossRef]

94. Cai, L.; Wang, J.; Peng, J.; Tan, Z.; Zhan, Z.; Tan, X.; Chen, Q. Characteristic of Microplastics in the Atmospheric Fallout from Dongguan City, China: Preliminary Research and First Evidence. Environ. Sci. Pollut. Res. 2017, 24, 24928-24935. [CrossRef] [PubMed]

95. Klein, M.; Fischer, E.K. Microplastic Abundance in Atmospheric Deposition within the Metropolitan Area of Hamburg, Germany. Sci. Total Environ. 2019, 685, 96-103. [CrossRef] [PubMed]

96. Abbasi, S.; Keshavarzi, B.; Moore, F.; Turner, A.; Kelly, F.J.; Dominguez, A.O.; Jaafarzadeh, N. Distribution and Potential Health Impacts of Microplastics and Microrubbers in Air and Street Dusts from Asaluyeh County, Iran. Environ. Pollut. 2019, 244, 153-164. [CrossRef]

97. Dris, R.; Gasperi, J.; Mirande, C.; Mandin, C.; Guerrouache, M.; Langlois, V.; Tassin, B. A First Overview of Textile Fibers, Including Microplastics, in Indoor and Outdoor Environments. Environ. Pollut. 2017, 221, 453-458. [CrossRef]

98. Liu, K.; Wang, X.; Fang, T.; Xu, P.; Zhu, L.; Li, D. Source and Potential Risk Assessment of Suspended Atmospheric Microplastics in Shanghai. Sci. Total Environ. 2019, 675, 462-471. [CrossRef]

99. Zhang, Y.; Kang, S.; Allen, S.; Allen, D.; Gao, T.; Sillanpää, M. Atmospheric Microplastics: A Review on Current Status and Perspectives. Earth Sci. Rev. 2020, 203, 103118. [CrossRef]

100. Li, J.; Liu, H.; Paul Chen, J. Microplastics in Freshwater Systems: A Review on Occurrence, Environmental Effects, and Methods for Microplastics Detection. Water Res. 2018, 137, 362-374. [CrossRef]

101. Li, J.; Zhang, K.; Zhang, H. Adsorption of Antibiotics on Microplastics. Environ. Pollut. 2018, 237, 460-467. [CrossRef]

102. Mintenig, S.; Bauerlein, P.; Koelmans, A.A.; Dekker, S.; van Wezel, A.P. Closing the gap between small and smaller: Towards an analytical protocol for the detection of micro- and nanoplastic in freshwater systems. In Proceedings of the MICRO 2016 International Conference, Lanzarote, Spain, 25-27 May 2016. 
103. Blom, M.T.; Chmela, E.; Oosterbroek, R.E.; Tijssen, R.; van den Berg, A. On-Chip Hydrodynamic Chromatography Separation and Detection of Nanoparticles and Biomolecules. Anal. Chem. 2003, 75, 6761-6768. [CrossRef]

104. Fu, W.; Min, J.; Jiang, W.; Li, Y.; Zhang, W. Separation, Characterization and Identification of Microplastics and Nanoplastics in the Environment. Sci. Total Environ. 2020, 721, 137561. [CrossRef]

105. Song, Y.K.; Hong, S.H.; Jang, M.; Han, G.M.; Rani, M.; Lee, J.; Shim, W.J. A Comparison of Microscopic and Spectroscopic Identification Methods for Analysis of Microplastics in Environmental Samples. Mar. Pollut. Bull. 2015, 93, 202-209. [CrossRef]

106. Goldstein, J.; Newbury, D.E.; Michael, J.R.; Ritchie, N.W.M.; Scott, J.H.J. Scanning Electron Microscopy and X-Ray Microanalysis, 4th ed.; Springer: Berlin/Heidelberg, Germany, 2017; ISBN 978-1-4939-6674-5.

107. Cooper, D.A.; Corcoran, P.L. Effects of Mechanical and Chemical Processes on the Degradation of Plastic Beach Debris on the Island of Kauai, Hawaii. Mar. Pollut. Bull. 2010, 60, 650-654. [CrossRef]

108. Baruah, A.; Sharma, A.; Sharma, S.; Nagraik, R. An Insight into Different Microplastic Detection Methods. Int. J. Environ. Sci. Technol. 2021. [CrossRef]

109. Savoca, S.; Bottari, T.; Fazio, E.; Bonsignore, M.; Mancuso, M.; Luna, G.M.; Romeo, T.; D’Urso, L.; Capillo, G.; Panarello, G.; et al. Plastics Occurrence in Juveniles of Engraulis Encrasicolus and Sardina Pilchardus in the Southern Tyrrhenian Sea. Sci. Total Environ. 2020, 718, 137457. [CrossRef]

110. Guo, J.-J.; Huang, X.-P.; Xiang, L.; Wang, Y.-Z.; Li, Y.-W.; Li, H.; Cai, Q.-Y.; Mo, C.-H.; Wong, M.-H. Source, Migration and Toxicology of Microplastics in Soil. Environ. Int. 2020, 137, 105263. [CrossRef]

111. Wright, S.L.; Kelly, F.J. Plastic and Human Health: A Micro Issue? Environ. Sci. Technol. 2017, 51, 6634-6647. [CrossRef]

112. Kirstein, I.V.; Hensel, F.; Gomiero, A.; Iordachescu, L.; Vianello, A.; Wittgren, H.B.; Vollertsen, J. Drinking Plastics?-Quantification and Qualification of Microplastics in Drinking Water Distribution Systems by MFTIR and Py-GCMS. Water Res. 2021, $188,116519$. [CrossRef]

113. Sivagami, M.; Selvambigai, M.; Devan, U.; Velangani, A.A.J.; Karmegam, N.; Biruntha, M.; Arun, A.; Kim, W.; Govarthanan, M.; Kumar, P. Extraction of Microplastics from Commonly Used Sea Salts in India and Their Toxicological Evaluation. Chemosphere 2021, 263, 128181. [CrossRef]

114. Barboza, L.G.A.; Dick Vethaak, A.; Lavorante, B.R.B.O.; Lundebye, A.-K.; Guilhermino, L. Marine Microplastic Debris: An Emerging Issue for Food Security, Food Safety and Human Health. Mar. Pollut. Bull. 2018, 133, 336-348. [CrossRef]

115. Huerta, E.; Mendoza Vega, J.; Quej, V.K.; de los Chi, J.A.; del Cid, L.S.; Quijano, C.; Escalona-Segura, G.; Gertsen, H.; Salánki, T.; van der Ploeg, M.; et al. Bioaccumulation of Microplastics in the Terrestrial Food Chain: An Example from Home Gardens in SE Mexico. EGU Gen. Assem. Conf. Abstr. 2017, 19, 15847.

116. Ouyang, M.-Y.; Liu, J.-H.; Wen, B.; Huang, J.-N.; Feng, X.-S.; Gao, J.-Z.; Chen, Z.-Z. Ecological Stoichiometric and Stable Isotopic Responses to Microplastics Are Modified by Food Conditions in Koi Carp. J. Hazard. Mater. 2021, 404, 124121. [CrossRef]

117. Wang, S.; Zhong, Z.; Li, Z.; Wang, X.; Gu, H.; Huang, W.; Fang, J.K.-H.; Shi, H.; Hu, M.; Wang, Y. Physiological Effects of Plastic Particles on Mussels Are Mediated by Food Presence. J. Hazard. Mater. 2021, 404, 124136. [CrossRef]

118. Walkinshaw, C.; Lindeque, P.K.; Thompson, R.; Tolhurst, T.; Cole, M. Microplastics and Seafood: Lower Trophic Organisms at Highest Risk of Contamination. Ecotoxicol. Environ. Saf. 2020, 190, 110066. [CrossRef]

119. Li, N.; Wu, X.; Zhuang, W.; Xia, L.; Chen, Y.; Wu, C.; Rao, Z.; Du, L.; Zhao, R.; Yi, M. Fish Consumption and Multiple Health Outcomes: Umbrella Review. Trends Food Sci. Technol. 2020, 99, 273-283. [CrossRef]

120. Alomar, C.; Sureda, A.; Capó, X.; Guijarro, B.; Tejada, S.; Deudero, S. Microplastic Ingestion by Mullus surmuletus Linnaeus, 1758 Fish and Its Potential for Causing Oxidative Stress. Environ. Res. 2017, 159, 135-142. [CrossRef] [PubMed]

121. Bellas, J.; Martínez-Armental, J.; Martínez-Cámara, A.; Besada, V.; Martínez-Gómez, C. Ingestion of Microplastics by Demersal Fish from the Spanish Atlantic and Mediterranean Coasts. Mar. Pollut. Bull. 2016, 109, 55-60. [CrossRef]

122. Cho, Y.; Shim, W.J.; Jang, M.; Han, G.M.; Hong, S.H. Abundance and Characteristics of Microplastics in Market Bivalves from South Korea. Environ. Pollut. 2019, 245, 1107-1116. [CrossRef]

123. Collard, F.; Gilbert, B.; Compère, P.; Eppe, G.; Das, K.; Jauniaux, T.; Parmentier, E. Microplastics in Livers of European Anchovies (Engraulis encrasicolus, L.). Environ. Pollut. 2017, 229, 1000-1005. [CrossRef]

124. Courtene-Jones, W.; Quinn, B.; Gary, S.F.; Mogg, A.O.M.; Narayanaswamy, B.E. Microplastic Pollution Identified in Deep-Sea Water and Ingested by Benthic Invertebrates in the Rockall Trough, North Atlantic Ocean. Environ. Pollut. 2017, 231, 271-280. [CrossRef]

125. Daniel, D.B.; Ashraf, P.M.; Thomas, S.N. Abundance, Characteristics and Seasonal Variation of Microplastics in Indian White Shrimps (Fenneropenaeus indicus) from Coastal Waters off Cochin, Kerala, India. Sci. Total Environ. 2020, 737, 139839. [CrossRef] [PubMed]

126. Güven, O.; Gökdağ, K.; Jovanović, B.; Kıdeyş, A.E. Microplastic Litter Composition of the Turkish Territorial Waters of the Mediterranean Sea, and Its Occurrence in the Gastrointestinal Tract of Fish. Environ. Pollut. 2017, 223, 286-294. [CrossRef] [PubMed]

127. Hermsen, E.; Pompe, R.; Besseling, E.; Koelmans, A.A. Detection of Low Numbers of Microplastics in North Sea Fish Using Strict Quality Assurance Criteria. Mar. Pollut. Bull. 2017, 122, 253-258. [CrossRef] [PubMed]

128. Jabeen, K.; Su, L.; Li, J.; Yang, D.; Tong, C.; Mu, J.; Shi, H. Microplastics and Mesoplastics in Fish from Coastal and Fresh Waters of China. Environ. Pollut. 2017, 221, 141-149. [CrossRef] 
129. Li, J.; Qu, X.; Su, L.; Zhang, W.; Yang, D.; Kolandhasamy, P.; Li, D.; Shi, H. Microplastics in Mussels along the Coastal Waters of China. Environ. Pollut. 2016, 214, 177-184. [CrossRef] [PubMed]

130. Lusher, A.L.; Hernandez-Milian, G.; O’Brien, J.; Berrow, S.; O'Connor, I.; Officer, R. Microplastic and Macroplastic Ingestion by a Deep Diving, Oceanic Cetacean: The True's Beaked Whale Mesoplodon mirus. Environ. Pollut. 2015, 199, 185-191. [CrossRef]

131. Lusher, A.L.; McHugh, M.; Thompson, R.C. Occurrence of Microplastics in the Gastrointestinal Tract of Pelagic and Demersal Fish from the English Channel. Mar. Pollut. Bull. 2013, 67, 94-99. [CrossRef]

132. Nadal, M.A.; Alomar, C.; Deudero, S. High Levels of Microplastic Ingestion by the Semipelagic Fish Bogue Boops boops (L.) around the Balearic Islands. Environ. Pollut. 2016, 214, 517-523. [CrossRef]

133. Neves, D.; Sobral, P.; Ferreira, J.L.; Pereira, T. Ingestion of Microplastics by Commercial Fish off the Portuguese Coast. Mar. Pollut. Bull. 2015, 101, 119-126. [CrossRef]

134. Ory, N.C.; Sobral, P.; Ferreira, J.L.; Thiel, M. Amberstripe Scad Decapterus muroadsi (Carangidae) Fish Ingest Blue Microplastics Resembling Their Copepod Prey along the Coast of Rapa Nui (Easter Island) in the South Pacific Subtropical Gyre. Sci. Total Environ. 2017, 586, 430-437. [CrossRef]

135. Van Cauwenberghe, L.; Claessens, M.; Vandegehuchte, M.B.; Janssen, C.R. Microplastics Are Taken up by Mussels (Mytilus edulis) and Lugworms (Arenicola marina) Living in Natural Habitats. Environ. Pollut. 2015, 199, 10-17. [CrossRef]

136. Van Cauwenberghe, L.; Janssen, C.R. Microplastics in Bivalves Cultured for Human Consumption. Environ. Pollut. 2014, 193, 65-70. [CrossRef] [PubMed]

137. Wang, J.; Wang, M.; Ru, S.; Liu, X. High Levels of Microplastic Pollution in the Sediments and Benthic Organisms of the South Yellow Sea, China. Sci. Total Environ. 2019, 651, 1661-1669. [CrossRef] [PubMed]

138. Zhu, L.; Wang, H.; Chen, B.; Sun, X.; Qu, K.; Xia, B. Microplastic Ingestion in Deep-Sea Fish from the South China Sea. Sci. Total Environ. 2019, 677, 493-501. [CrossRef] [PubMed]

139. Baalkhuyur, F.M.; Qurban, M.A.; Panickan, P.; Duarte, C.M. Microplastics in Fishes of Commercial and Ecological Importance from the Western Arabian Gulf. Mar. Pollut. Bull. 2020, 152, 110920. [CrossRef]

140. Miranda, D.d.A.; de Carvalho-Souza, G.F. Are We Eating Plastic-Ingesting Fish? Mar. Pollut. Bull. 2016, 103, 109-114. [CrossRef] [PubMed]

141. Barboza, L.G.A.; Lopes, C.; Oliveira, P.; Bessa, F.; Otero, V.; Henriques, B.; Raimundo, J.; Caetano, M.; Vale, C.; Guilhermino, L. Microplastics in Wild Fish from North East Atlantic Ocean and Its Potential for Causing Neurotoxic Effects, Lipid Oxidative Damage, and Human Health Risks Associated with Ingestion Exposure. Sci. Total Environ. 2020, 717, 134625. [CrossRef]

142. Akhbarizadeh, R.; Moore, F.; Keshavarzi, B. Investigating Microplastics Bioaccumulation and Biomagnification in Seafood from the Persian Gulf: A Threat to Human Health? Food Addit. Contam. 2019, 36, 1696-1708. [CrossRef] [PubMed]

143. Crawford, C.B.; Quinn, B. Microplastic Pollutants; Elsevier: Amsterdam, The Netherlands, 2017; ISBN 978-0-12-810469-9.

144. Ory, N.; Chagnon, C.; Felix, F.; Fernández, C.; Ferreira, J.L.; Gallardo, C.; Garcés Ordóñez, O.; Henostroza, A.; Laaz, E.; Mizraji, R.; et al. Low Prevalence of Microplastic Contamination in Planktivorous Fish Species from the Southeast Pacific Ocean. Mar. Pollut. Bull. 2018, 127, 211-216. [CrossRef]

145. Savoca, S.; Capillo, G.; Mancuso, M.; Bottari, T.; Crupi, R.; Branca, C.; Romano, V.; Faggio, C.; D'Angelo, G.; Spanò, N. Microplastics Occurrence in the Tyrrhenian Waters and in the Gastrointestinal Tract of Two Congener Species of Seabreams. Environ. Toxicol. Pharmacol. 2019, 67, 35-41. [CrossRef]

146. Strungaru, S.-A.; Jijie, R.; Nicoara, M.; Plavan, G.; Faggio, C. Micro- (Nano) Plastics in Freshwater Ecosystems: Abundance, Toxicological Impact and Quantification Methodology. Trends Anal. Chem. 2019, 110, 116-128. [CrossRef]

147. Hossain, M.S.; Rahman, M.S.; Uddin, M.N.; Sharifuzzaman, S.M.; Chowdhury, S.R.; Sarker, S.; Nawaz Chowdhury, M.S. Microplastic Contamination in Penaeid Shrimp from the Northern Bay of Bengal. Chemosphere 2020, 238, 124688. [CrossRef]

148. Karbalaei, S.; Golieskardi, A.; Watt, D.U.; Boiret, M.; Hanachi, P.; Walker, T.R.; Karami, A. Analysis and Inorganic Composition of Microplastics in Commercial Malaysian Fish Meals. Mar. Pollut. Bull. 2020, 150, 110687. [CrossRef]

149. Garcia, F.; de Carvalho, A.R.; Riem-Galliano, L.; Tudesque, L.; Albignac, M.; ter Halle, A.; Cucherousset, J. Stable Isotope Insights into Microplastic Contamination within Freshwater Food Webs. Environ. Sci. Technol. 2021, 55, 1024-1035. [CrossRef]

150. Pironti, C.; Cucciniello, R.; Camin, F.; Tonon, A.; Motta, O.; Proto, A. Determination of the 13C/12C Carbon Isotope Ratio in Carbonates and Bicarbonates by 13C NMR Spectroscopy. Anal. Chem. 2017, 89, 11413-11418. [CrossRef] [PubMed]

151. Zanasi, R.; Alfano, D.; Scarabino, C.; Motta, O.; Viglione, R.G.; Proto, A. Determination of 13C/12C Carbon Isotope Ratio. Anal. Chem. 2006, 78, 3080-3083. [CrossRef]

152. Ricciardi, M.; Pironti, C.; Motta, O.; Fiorillo, R.; Camin, F.; Faggiano, A.; Proto, A. Investigations on Historical Monuments' Deterioration through Chemical and Isotopic Analyses: An Italian Case Study. Environ. Sci. Pollut. Res. 2021. [CrossRef] [PubMed]

153. Pironti, C.; Proto, A.; Camin, F.; Cucciniello, R.; Zarrella, I.; Motta, O. FTIR and NDIR Spectroscopies as Valuable Alternatives to IRMS Spectrometry for the $\triangle 13 C$ Analysis of Food. Talanta 2016, 160, 276-281. [CrossRef] [PubMed]

154. Motta, O.; de Caro, F.; Quarto, F.; Proto, A. New FTIR Methodology for the Evaluation of 13C/12C Isotope Ratio in Helicobacter Pylori Infection Diagnosis. J. Infect. 2009, 59, 90-94. [CrossRef]

155. Proto, A.; Cucciniello, R.; Rossi, F.; Motta, O. Stable Carbon Isotope Ratio in Atmospheric $\mathrm{CO}_{2}$ Collected by New Diffusive Devices. Environ. Sci. Pollut. Res. 2014, 21, 3182-3186. [CrossRef] [PubMed] 
156. Pironti, C.; Ricciardi, M.; Proto, A.; Cucciniello, R.; Fiorentino, A.; Fiorillo, R.; Motta, O. New Analytical Approach to Monitoring Air Quality in Historical Monuments through the Isotopic Ratio of $\mathrm{CO}_{2}$. Environ. Sci. Pollut. Res. 2021. [CrossRef]

157. Motta, O.; Pironti, C.; Ricciardi, M.; Rostagno, C.; Bolzacchini, E.; Ferrero, L.; Cucciniello, R.; Proto, A. Leonardo Da Vinci's “Last Supper": A Case Study to Evaluate the Influence of Visitors on the Museum Preservation Systems. Environ. Sci. Pollut. Res. 2021. [CrossRef]

158. Pironti, C.; Motta, O.; Ricciardi, M.; Camin, F.; Cucciniello, R.; Proto, A. Characterization and Authentication of Commercial Cleaning Products Formulated with Biobased Surfactants by Stable Carbon Isotope Ratio. Talanta 2020, 219, 121256. [CrossRef] [PubMed]

159. Taipale, S.J.; Peltomaa, E.; Kukkonen, J.V.K.; Kainz, M.J.; Kautonen, P.; Tiirola, M. Tracing the Fate of Microplastic Carbon in the Aquatic Food Web by Compound-Specific Isotope Analysis. Sci. Rep. 2019, 9, 19894. [CrossRef]

160. Berto, D.; Rampazzo, F.; Gion, C.; Noventa, S.; Formalewicz, M.; Ronchi, F.; Traldi, U.; Giorgi, G. Elemental analyzer/isotope ratio mass spectrometry (EA/IRMS) as a tool to characterize plastic polymers in a marine environment. In Plastics in the Environment; IntechOpen: London, UK, 2019; pp. 37-54.

161. Birch, Q.T.; Potter, P.M.; Pinto, P.X.; Dionysiou, D.D.; Al-Abed, S.R. Isotope Ratio Mass Spectrometry and Spectroscopic Techniques for Microplastics Characterization. Talanta 2021, 224, 121743. [CrossRef] [PubMed]

162. Gündoğdu, S. Contamination of Table Salts from Turkey with Microplastics. Food Addit. Contam. 2018, 35, 1006-1014. [CrossRef]

163. Iñiguez, M.E.; Conesa, J.A.; Fullana, A. Microplastics in Spanish Table Salt. Sci. Rep. 2017, 7, 8620. [CrossRef] [PubMed]

164. Karami, A.; Golieskardi, A.; Keong Choo, C.; Larat, V.; Galloway, T.S.; Salamatinia, B. The Presence of Microplastics in Commercial Salts from Different Countries. Sci. Rep. 2017, 7, 46173. [CrossRef] [PubMed]

165. Kim, J.-S.; Lee, H.-J.; Kim, S.-K.; Kim, H.-J. Global Pattern of Microplastics (MPs) in Commercial Food-Grade Salts: Sea Salt as an Indicator of Seawater MP Pollution. Environ. Sci. Technol. 2018, 52, 12819-12828. [CrossRef] [PubMed]

166. Kosuth, M.; Mason, S.A.; Wattenberg, E.V. Anthropogenic Contamination of Tap Water, Beer, and Sea Salt. PLoS ONE 2018, 13. [CrossRef] [PubMed]

167. Lee, H.; Kunz, A.; Shim, W.J.; Walther, B.A. Microplastic Contamination of Table Salts from Taiwan, Including a Global Review. Sci. Rep. 2019, 9, 10145. [CrossRef]

168. Renzi, M.; Blašković, A. Litter \& Microplastics Features in Table Salts from Marine Origin: Italian versus Croatian Brands. Mar. Pollut. Bull. 2018, 135, 62-68. [CrossRef]

169. Seth, C.K.; Shriwastav, A. Contamination of Indian Sea Salts with Microplastics and a Potential Prevention Strategy. Environ. Sci. Pollut. Res. 2018, 25, 30122-30131. [CrossRef] [PubMed]

170. Yang, D.; Shi, H.; Li, L.; Li, J.; Jabeen, K.; Kolandhasamy, P. Microplastic Pollution in Table Salts from China. Environ. Sci. Technol. 2015, 49, 13622-13627. [CrossRef] [PubMed]

171. Danopoulos, E.; Jenner, L.; Twiddy, M.; Rotchell, J.M. Microplastic Contamination of Salt Intended for Human Consumption: A Systematic Review and Meta-Analysis. SN Appl. Sci. 2020, 2, 1950. [CrossRef]

172. Lee, H.-J.; Song, N.-S.; Kim, J.-S.; Kim, S.-K. Variation and Uncertainty of Microplastics in Commercial Table Salts: Critical Review and Validation. J. Hazard. Mater. 2021, 402, 123743. [CrossRef]

173. Peixoto, D.; Pinheiro, C.; Amorim, J.; Oliva-Teles, L.; Guilhermino, L.; Vieira, M.N. Microplastic Pollution in Commercial Salt for Human Consumption: A Review. Estuar. Coast. Shelf Sci. 2019, 219, 161-168. [CrossRef]

174. Zhang, Q.; Xu, E.G.; Li, J.; Chen, Q.; Ma, L.; Zeng, E.Y.; Shi, H. A Review of Microplastics in Table Salt, Drinking Water, and Air: Direct Human Exposure. Environ. Sci. Technol. 2020, 54, 3740-3751. [CrossRef]

175. Lee, P.S.; Jung, S.M. Quantitative Analysis of Microplastics Coagulation-Removal Process for Clean Sea Salt Production. Int. J. Environ. Sci. Technol. 2021. [CrossRef]

176. WHO. Issues New Guidance on Dietary Salt and Potassium. Available online: https://www.who.int/news/item/31-01-2013 -who-issues-new-guidance-on-dietary-salt-and-potassium (accessed on 31 August 2021).

177. Mozaffarian, D.; Fahimi, S.; Singh, G.M.; Micha, R.; Khatibzadeh, S.; Engell, R.E.; Lim, S.; Danaei, G.; Ezzati, M.; Powles, J. Global Sodium Consumption and Death from Cardiovascular Causes. N. Engl. J. Med. 2014, 371, 624-634. [CrossRef]

178. Danopoulos, E.; Twiddy, M.; Rotchell, J.M. Microplastic Contamination of Drinking Water: A Systematic Review. PLoS ONE 2020, 15, e0236838. [CrossRef]

179. Li, Y.; Li, W.; Jarvis, P.; Zhou, W.; Zhang, J.; Chen, J.; Tan, Q.; Tian, Y. Occurrence, Removal and Potential Threats Associated with Microplastics in Drinking Water Sources. J. Environ. Chem. Eng. 2020, 8, 104527. [CrossRef]

180. Mason, S.A.; Welch, V.G.; Neratko, J. Synthetic Polymer Contamination in Bottled Water. Front. Chem. 2018, 6. [CrossRef]

181. Mintenig, S.M.; Löder, M.G.J.; Primpke, S.; Gerdts, G. Low Numbers of Microplastics Detected in Drinking Water from Ground Water Sources. Sci. Total Environ. 2019, 648, 631-635. [CrossRef]

182. Oßmann, B.E.; Sarau, G.; Holtmannspötter, H.; Pischetsrieder, M.; Christiansen, S.H.; Dicke, W. Small-Sized Microplastics and Pigmented Particles in Bottled Mineral Water. Water Res. 2018, 141, 307-316. [CrossRef] [PubMed]

183. Pivokonsky, M.; Cermakova, L.; Novotna, K.; Peer, P.; Cajthaml, T.; Janda, V. Occurrence of Microplastics in Raw and Treated Drinking Water. Sci. Total Environ. 2018, 643, 1644-1651. [CrossRef]

184. Schymanski, D.; Goldbeck, C.; Humpf, H.-U.; Fürst, P. Analysis of Microplastics in Water by Micro-Raman Spectroscopy: Release of Plastic Particles from Different Packaging into Mineral Water. Water Res. 2018, 129, 154-162. [CrossRef] [PubMed] 
185. Wang, Z.; Lin, T.; Chen, W. Occurrence and Removal of Microplastics in an Advanced Drinking Water Treatment Plant (ADWTP). Sci. Total Environ. 2020, 700, 134520. [CrossRef]

186. Welle, F.; Franz, R. Microplastic in Bottled Natural Mineral Water-Literature Review and Considerations on Exposure and Risk Assessment. Food Addit. Contam. 2018, 35, 2482-2492. [CrossRef] [PubMed]

187. WHO. 2019 Microplastics in Drinking-Water. Available online: http://www.who.int/water_sanitation_health/publications/ microplastics-in-drinking-water/en/ (accessed on 2 July 2020).

188. Cox, K.D.; Covernton, G.A.; Davies, H.L.; Dower, J.F.; Juanes, F.; Dudas, S.E. Human Consumption of Microplastics. Environ. Sci. Technol. 2019, 53, 7068-7074. [CrossRef]

189. Shruti, V.C.; Pérez-Guevara, F.; Elizalde-Martínez, I.; Kutralam-Muniasamy, G. First Study of Its Kind on the Microplastic Contamination of Soft Drinks, Cold Tea and Energy Drinks-Future Research and Environmental Considerations. Sci. Total Environ. 2020, 726, 138580. [CrossRef] [PubMed]

190. Gonzalez Colín, M.; Domínguez, E.R.; Suppen Reynaga, N. Evaluación Técnica, Económica y Ambiental de La Producción Más Limpia En Una Empresa de Bebidas Gaseosas. Tecnología Ciencia Educación 2007, 22, 78-83.

191. Lachenmeier, D.W.; Kocareva, J.; Noack, D.; Kuballa, T. Microplastic Identification in German Beer-an Artefact of Laboratory Contamination? Deutsche Lebensmittel Rundschau 2015, 111, 437-440.

192. Liebezeit, G.; Liebezeit, E. Synthetic Particles as Contaminants in German Beers. Food Addit. Contam. 2014, 31, 1574-1578. [CrossRef]

193. Food and Agriculture Organization of the United Nations. The State of Food Security and Nutrition in the World: Safeguarding against Economic Slowdowns and Downturns; FAO: Rome, Italy, 2019; ISBN 978-92-5-131570-5.

194. Burke, N.; Zacharski, K.A.; Southern, M.; Hogan, P.; Ryan, M.P.; Adley, C.C. The Dairy Industry: Process, Monitoring, Standards, and Quality. Descr. Food Sci. 2018. [CrossRef]

195. Kutralam-Muniasamy, G.; Pérez-Guevara, F.; Elizalde-Martínez, I.; Shruti, V.C. Branded Milks-Are They Immune from Microplastics Contamination? Sci. Total Environ. 2020, 714, 136823. [CrossRef]

196. Li, D.; Shi, Y.; Yang, L.; Xiao, L.; Kehoe, D.K.; Gun'ko, Y.K.; Boland, J.J.; Wang, J.J. Microplastic Release from the Degradation of Polypropylene Feeding Bottles during Infant Formula Preparation. Nat. Food 2020, 1, 746-754. [CrossRef]

197. Liebezeit, G.; Liebezeit, E. Non-Pollen Particulates in Honey and Sugar. Food Addit. Contam. 2013, 30, 2136-2140. [CrossRef]

198. Mühlschlegel, P.; Hauk, A.; Walter, U.; Sieber, R. Lack of Evidence for Microplastic Contamination in Honey. Food Addit. Contam. 2017, 34, 1982-1989. [CrossRef] [PubMed]

199. Diaz-Basantes, M.F.; Conesa, J.A.; Fullana, A. Microplastics in Honey, Beer, Milk and Refreshments in Ecuador as Emerging Contaminants. Sustainability 2020, 12, 5514. [CrossRef]

200. Oliveri Conti, G.; Ferrante, M.; Banni, M.; Favara, C.; Nicolosi, I.; Cristaldi, A.; Fiore, M.; Zuccarello, P. Micro- and Nano-Plastics in Edible Fruit and Vegetables. The First Diet Risks Assessment for the General Population. Environ. Res. 2020, 187, 109677. [CrossRef] [PubMed]

201. Huerta Lwanga, E.; Mendoza Vega, J.; Ku Quej, V.; de los Chi, J.A.; del Cid, L.S.; Chi, C.; Escalona Segura, G.; Gertsen, H.; Salánki, T.; van der Ploeg, M.; et al. Field Evidence for Transfer of Plastic Debris along a Terrestrial Food Chain. Sci. Rep. 2017, 7, 14071. [CrossRef]

202. Yan, Z.; Zhao, H.; Zhao, Y.; Zhu, Q.; Qiao, R.; Ren, H.; Zhang, Y. An Efficient Method for Extracting Microplastics from Feces of Different Species. J. Hazard. Mater. 2020, 384, 121489. [CrossRef]

203. Huang, Y.; Chapman, J.; Deng, Y.; Cozzolino, D. Rapid Measurement of Microplastic Contamination in Chicken Meat by Mid Infrared Spectroscopy and Chemometrics: A Feasibility Study. Food Control 2020, 113, 107187. [CrossRef]

204. Wu, R.-T.; Cai, Y.-F.; Chen, Y.-X.; Yang, Y.-W.; Xing, S.-C.; Liao, X.-D. Occurrence of Microplastic in Livestock and Poultry Manure in South China. Environ. Pollut. 2021, 277, 116790. [CrossRef]

205. Kedzierski, M.; Lechat, B.; Sire, O.; le Maguer, G.; le Tilly, V.; Bruzaud, S. Microplastic Contamination of Packaged Meat: Occurrence and Associated Risks. Food Packag. Shelf Life 2020, 24, 100489. [CrossRef]

206. Shruti, V.C.; Pérez-Guevara, F.; Elizalde-Martínez, I.; Kutralam-Muniasamy, G. Toward a Unified Framework for Investigating Micro (Nano) Plastics in Packaged Beverages Intended for Human Consumption. Environ. Pollut. 2020, 12, 115811. [CrossRef]

207. Du, F.; Cai, H.; Zhang, Q.; Chen, Q.; Shi, H. Microplastics in Take-out Food Containers. J. Hazard. Mater. 2020, $399,122969$. [CrossRef]

208. Catarino, A.I.; Macchia, V.; Sanderson, W.G.; Thompson, R.C.; Henry, T.B. Low Levels of Microplastics (MP) in Wild Mussels Indicate That MP Ingestion by Humans Is Minimal Compared to Exposure via Household Fibres Fallout during a Meal. Environ. Pollut. 2018, 237, 675-684. [CrossRef]

209. Liebezeit, G.; Liebezeit, E. Origin of Synthetic Particles in Honeys. Pol. J. Food Nutr. Sci. 2015, 65, 143-147. [CrossRef]

210. Prata, J.C. Airborne Microplastics: Consequences to Human Health? Environ. Pollut. 2018, 234, 115-126. [CrossRef] [PubMed]

211. Vianello, A.; Jensen, R.L.; Liu, L.; Vollertsen, J. Simulating Human Exposure to Indoor Airborne Microplastics Using a Breathing Thermal Manikin. Sci. Rep. 2019, 9, 1-11. [CrossRef]

212. Prata, J.C.; da Costa, J.P.; Lopes, I.; Duarte, A.C.; Rocha-Santos, T. Environmental Exposure to Microplastics: An Overview on Possible Human Health Effects. Sci. Total Environ. 2020, 702, 134455. [CrossRef]

213. Kremer, A.M.; Pal, T.M.; Boleij, J.S.M.; Schouten, J.P.; Rijcken, B. Airway Hyper-Responsiveness and the Prevalence of WorkRelated Symptoms in Workers Exposed to Irritants. Am. J. Ind. Med. 1994, 26, 655-669. [CrossRef] 
214. Muittari, A.; Veneskoski, T. Natural and Synthetic Fibers as Causes of Asthma and Rhinitis. Ann. Allergy 1978, 41, 48-50.

215. Wright, S.L.; Gouin, T.; Koelmans, A.A.; Scheuermann, L. Development of Screening Criteria for Microplastic Particles in Air and Atmospheric Deposition: Critical Review and Applicability towards Assessing Human Exposure. Microplastics Nanoplastics 2021, 1, 6. [CrossRef]

216. Revel, M.; Châtel, A.; Mouneyrac, C. Micro(Nano)Plastics: A Threat to Human Health? Curr. Opin. Environ. Sci. Health 2018, 1, 17-23. [CrossRef]

217. Moore, J.D.; Ototake, M.; Nakanishi, T. Particulate Antigen Uptake during Immersion Immunisation of Fish: The Effectiveness of Prolonged Exposure and the Roles of Skin and Gill. Fish Shellfish Immunol. 1998, 8, 393-408. [CrossRef]

218. Schirinzi, G.F.; Pérez-Pomeda, I.; Sanchís, J.; Rossini, C.; Farré, M.; Barceló, D. Cytotoxic Effects of Commonly Used Nanomaterials and Microplastics on Cerebral and Epithelial Human Cells. Environ. Res. 2017, 159, 579-587. [CrossRef] [PubMed]

219. Freedman, B.J. Persorption of Raw Starch: A Cause of Senile Dementia? Med. Hypotheses 1991, 35, 85-87. [CrossRef]

220. Steffens, K.-J. Persorption-Criticism and agreement as based upon in vitro and in vivo studies on mammals. In Absorption of Orally Administered Enzymes; Gardner, M.L.G., Steffens, K.-J., Eds.; Springer: Berlin/Heidelberg, Germany, $1995 ;$ pp. 9-21.

221. Volkheimer, G. The phenomenon of persorption: Persorption, dissemination, and elimination of microparticles. In Old Herborn University Seminar Monograph; Herborn Litterae; Old Herborn University: Herborn, Germany, 2001; Volume 14, pp. 7-18.

222. Volkheimer, G.; Schulz, F.H. The phenomenon of persorption. Digestion 1968, 1, 213-218. [CrossRef] [PubMed]

223. Mohamed Nor, N.H.; Kooi, M.; Diepens, N.J.; Koelmans, A.A. Lifetime Accumulation of Microplastic in Children and Adults. Environ. Sci. Technol. 2021, 55, 5084-5096. [CrossRef] [PubMed]

224. Schell, T.; Rico, A.; Vighi, M. Occurrence, Fate and Fluxes of Plastics and Microplastics in Terrestrial and Freshwater Ecosystems. Rev. Environ. Contam. Toxicol. 2020, 250, 1-43. [CrossRef]

225. Alimba, C.G.; Faggio, C. Microplastics in the Marine Environment: Current Trends in Environmental Pollution and Mechanisms of Toxicological Profile. Environ. Toxicol. Pharmacol. 2019, 68, 61-74. [CrossRef]

226. Krause, S.; Baranov, V.; Nel, H.A.; Drummond, J.; Kukkola, A.; Hoellein, T.; Smith, G.S.; Lewandowski, J.; Bonnet, B.; Packman, A.I. Gathering at the Top? Environmental Controls of Microplastic Uptake and Biomagnification in Freshwater Food Webs. Environ. Pollut. 2020, 268, 115750. [CrossRef]

227. Albano, M.; Panarello, G.; di Paola, D.; Capparucci, F.; Crupi, R.; Gugliandolo, E.; Spanò, N.; Capillo, G.; Savoca, S. The Influence of Polystyrene Microspheres Abundance on Development and Feeding Behavior of Artemia salina (Linnaeus, 1758). Appl. Sci. 2021, 11, 3352. [CrossRef]

228. Gualtieri, M.; Andrioletti, M.; Mantecca, P.; Vismara, C.; Camatini, M. Impact of Tire Debris on in Vitro and in Vivo Systems. Part. Fibre Toxicol. 2005, 2, 1. [CrossRef]

229. Noventa, S.; Boyles, M.S.P.; Seifert, A.; Belluco, S.; Jiménez, A.S.; Johnston, H.J.; Tran, L.; Fernandes, T.F.; Mughini-Gras, L.; Orsini, M.; et al. Paradigms to Assess the Human Health Risks of Nano- and Microplastics. Microplastics Nanoplastics $2021,1,9$. [CrossRef]

230. Yee, M.S.-L.; Hii, L.-W.; Looi, C.K.; Lim, W.-M.; Wong, S.-F.; Kok, Y.-Y.; Tan, B.-K.; Wong, C.-Y.; Leong, C.-O. Impact of Microplastics and Nanoplastics on Human Health. Nanomaterials 2021, 11, 496. [CrossRef] [PubMed]

231. Mahler, G.J.; Esch, M.B.; Tako, E.; Southard, T.L.; Archer, S.D.; Glahn, R.P.; Shuler, M.L. Oral Exposure to Polystyrene Nanoparticles Affects Iron Absorption. Nat. Nanotech. 2012, 7, 264-271. [CrossRef] [PubMed]

232. Heddagaard, F.E.; Møller, P. Hazard Assessment of Small-Size Plastic Particles: Is the Conceptual Framework of Particle Toxicology Useful? Food Chem. Toxicol. 2020, 136, 111106. [CrossRef] [PubMed]

233. Green, T.R.; Fisher, J.; Stone, M.; Wroblewski, B.M.; Ingham, E. Polyethylene Particles of a ‘Critical Size’ Are Necessary for the Induction of Cytokines by Macrophages in Vitro. Biomaterials 1998, 19, 2297-2302. [CrossRef]

234. Liu, A.; Richards, L.; Bladen, C.L.; Ingham, E.; Fisher, J.; Tipper, J.L. The Biological Response to Nanometre-Sized Polymer Particles. Acta Biomater. 2015, 23, 38-51. [CrossRef] [PubMed]

235. Petit, A.; Catelas, I.; Antoniou, J.; Zukor, D.J.; Huk, O.L. Differential Apoptotic Response of J774 Macrophages to Alumina and Ultra-High-Molecular-Weight Polyethylene Particles. J. Orthop. Res. 2002, 20, 9-15. [CrossRef]

236. Forte, M.; Iachetta, G.; Tussellino, M.; Carotenuto, R.; Prisco, M.; de Falco, M.; Laforgia, V.; Valiante, S. Polystyrene Nanoparticles Internalization in Human Gastric Adenocarcinoma Cells. Toxicol. In Vitro 2016, 31, 126-136. [CrossRef] [PubMed]

237. Fröhlich, E.; Meindl, C.; Wagner, K.; Leitinger, G.; Roblegg, E. Use of Whole Genome Expression Analysis in the Toxicity Screening of Nanoparticles. Toxicol. Appl. Pharmacol. 2014, 280, 272-284. [CrossRef]

238. Wu, B.; Wu, X.; Liu, S.; Wang, Z.; Chen, L. Size-Dependent Effects of Polystyrene Microplastics on Cytotoxicity and Efflux Pump Inhibition in Human Caco-2 cells. Chemosphere 2019, 221, 333-341. [CrossRef]

239. Deng, Y.; Zhang, Y.; Lemos, B.; Ren, H. Tissue Accumulation of Microplastics in Mice and Biomarker Responses Suggest Widespread Health Risks of Exposure. Sci. Rep. 2017, 7, 46687. [CrossRef]

240. Deng, Y.; Zhang, Y. Response to Uptake of Microplastics and Related Health Effects: A Critical Discussion of Deng et al., Scientific Reports 7: 46687, 2017. Arch. Toxicol. 2019, 93, 213-215. [CrossRef]

241. Lu, L.; Wan, Z.; Luo, T.; Fu, Z.; Jin, Y. Polystyrene Microplastics Induce Gut Microbiota Dysbiosis and Hepatic Lipid Metabolism Disorder in Mice. Sci. Total Environ. 2018, 631, 449-458. [CrossRef] [PubMed] 
242. Stock, V.; Böhmert, L.; Lisicki, E.; Block, R.; Cara-Carmona, J.; Pack, L.K.; Selb, R.; Lichtenstein, D.; Voss, L.; Henderson, C.J. Uptake and Effects of Orally Ingested Polystyrene Microplastic Particles in Vitro and in Vivo. Arch. Toxicol. 2019, 93, 1817-1833. [CrossRef]

243. Ruenraroengsak, P.; Tetley, T.D. Differential Bioreactivity of Neutral, Cationic and Anionic Polystyrene Nanoparticles with Cells from the Human Alveolar Compartment: Robust Response of Alveolar Type 1 Epithelial Cells. Part. Fibre Toxicol. 2015, 12, 19. [CrossRef]

244. Meindl, C.; Kueznik, T.; Bösch, M.; Roblegg, E.; Fröhlich, E. Intracellular Calcium Levels as Screening Tool for Nanoparticle Toxicity. J. Appl. Toxicol. 2015, 35, 1150-1159. [CrossRef]

245. Zhang, M.; Li, J.; Xing, G.; He, R.; Li, W.; Song, Y.; Guo, H. Variation in the Internalization of Differently Sized Nanoparticles Induces Different DNA-Damaging Effects on a Macrophage Cell Line. Arch. Toxicol. 2011, 85, 1575-1588. [CrossRef] [PubMed]

246. Ferraro, D.; Anselmi-Tamburini, U.; Tredici, I.G.; Ricci, V.; Sommi, P. Overestimation of Nanoparticles-Induced DNA Damage Determined by the Comet Assay. Nanotoxicology 2016, 10, 861-870. [CrossRef] [PubMed]

247. Poma, A.; Vecchiotti, G.; Colafarina, S.; Zarivi, O.; Aloisi, M.; Arrizza, L.; Chichiriccò, G.; di Carlo, P. In Vitro Genotoxicity of Polystyrene Nanoparticles on the Human Fibroblast Hs27 Cell Line. Nanomaterials 2019, 9, 1299. [CrossRef] [PubMed]

248. Lehner, R.; Weder, C.; Petri-Fink, A.; Rothen-Rutishauser, B. Emergence of Nanoplastic in the Environment and Possible Impact on Human Health. Environ. Sci. Technol. 2019, 53, 1748-1765. [CrossRef]

249. Salomon, J.J.; Ehrhardt, C. Nanoparticles Attenuate P-Glycoprotein/MDR1 Function in A549 Human Alveolar Epithelial Cells. Eur. J. Pharm. Biopharm. 2011, 77, 392-397. [CrossRef] [PubMed]

250. Xu, M.; Halimu, G.; Zhang, Q.; Song, Y.; Fu, X.; Li, Y.; Li, Y.; Zhang, H. Internalization and Toxicity: A Preliminary Study of Effects of Nanoplastic Particles on Human Lung Epithelial Cell. Sci. Total Environ. 2019, 694, 133794. [CrossRef] [PubMed]

251. Shi, Q.; Tang, J.; Wang, L.; Liu, R.; Giesy, J.P. Combined Cytotoxicity of Polystyrene Nanoplastics and Phthalate Esters on Human Lung Epithelial A549 Cells and Its Mechanism. Ecotoxicol. Environ. Saf. 2021, 213, 112041. [CrossRef]

252. Deville, S.; Penjweini, R.; Smisdom, N.; Notelaers, K.; Nelissen, I.; Hooyberghs, J.; Ameloot, M. Intracellular Dynamics and Fate of Polystyrene Nanoparticles in A549 Lung Epithelial Cells Monitored by Image (Cross-) Correlation Spectroscopy and Single Particle Tracking. Biochim. Biophys. Acta 2015, 1853, 2411-2419. [CrossRef]

253. Goodman, K.E.; Hare, J.T.; Khamis, Z.I.; Hua, T.; Sang, Q.-X.A. Exposure of Human Lung Cells to Polystyrene Microplastics Significantly Retards Cell Proliferation and Triggers Morphological Changes. Chem. Res. Toxicol. 2021, 34, 1069-1081. [CrossRef] [PubMed]

254. Xu, H.; Dinsdale, D.; Nemery, B.; Hoet, P.H.M. Role of Residual Additives in the Cytotoxicity and Cytokine Release Caused by Polyvinyl Chloride Particles in Pulmonary Cell Cultures. Toxicol. Sci. 2003, 72, 92-102. [CrossRef]

255. Xu, H.; Hoet, P.H.M.; Nemery, B. In Vitro Toxicity Assessment of Polyvinyl Chloride Particles and Comparison of Six Cellular Systems. J. Toxicol. Environ. Health A 2002, 65, 1141-1159. [CrossRef]

256. Domenech, J.; Hernández, A.; Rubio, L.; Marcos, R.; Cortés, C. Interactions of Polystyrene Nanoplastics with in Vitro Models of the Human Intestinal Barrier. Arch. Toxicol. 2020, 94, 2997-3012. [CrossRef] [PubMed]

257. Walczak, A.P.; Kramer, E.; Hendriksen, P.J.M.; Tromp, P.; Helsper, J.P.F.G.; van der Zande, M.; Rietjens, I.M.C.M.; Bouwmeester, H. Translocation of Differently Sized and Charged Polystyrene Nanoparticles in in Vitro Intestinal Cell Models of Increasing Complexity. Nanotoxicology 2015, 9, 453-461. [CrossRef] [PubMed]

258. Dos Santos, T.; Varela, J.; Lynch, I.; Salvati, A.; Dawson, K.A. Effects of Transport Inhibitors on the Cellular Uptake of Carboxylated Polystyrene Nanoparticles in Different Cell Lines. PLoS ONE 2011, 6, e24438. [CrossRef]

259. Jeon, S.; Clavadetscher, J.; Lee, D.-K.; Chankeshwara, S.V.; Bradley, M.; Cho, W.-S. Surface Charge-Dependent Cellular Uptake of Polystyrene Nanoparticles. Nanomaterials 2018, 8, 1028. [CrossRef]

260. Banerjee, A.; Qi, J.; Gogoi, R.; Wong, J.; Mitragotri, S. Role of Nanoparticle Size, Shape and Surface Chemistry in Oral Drug Delivery. J. Control. Release 2016, 238, 176-185. [CrossRef]

261. Andrady, A.L. Microplastics in the Marine Environment. Mar. Pollut. Bull. 2011, 62, 1596-1605. [CrossRef]

262. Hahladakis, J.N.; Velis, C.A.; Weber, R.; Iacovidou, E.; Purnell, P. An Overview of Chemical Additives Present in Plastics: Migration, Release, Fate and Environmental Impact during Their Use, Disposal and Recycling. J. Hazard. Mater. 2018, 344, 179-199. [CrossRef]

263. Cormier, B.; Gambardella, C.; Tato, T.; Perdriat, Q.; Costa, E.; Veclin, C.; le Bihanic, F.; Grassl, B.; Dubocq, F.; Kärrman, A.; et al. Chemicals Sorbed to Environmental Microplastics Are Toxic to Early Life Stages of Aquatic Organisms. Ecotoxicol. Environ. Saf. 2021, 208, 111665. [CrossRef]

264. Lamb, J.B.; Willis, B.L.; Fiorenza, E.A.; Couch, C.S.; Howard, R.; Rader, D.N.; True, J.D.; Kelly, L.A.; Ahmad, A.; Jompa, J.; et al. Plastic Waste Associated with Disease on Coral Reefs. Science 2018, 359, 460-462. [CrossRef]

265. Zhao, Y.-B.; Gao, P.-P.; Ni, H.-G. A Chemical Time Bomb: Future Risks of Microplastics. Water Air Soil Pollut. 2019, $230,268$. [CrossRef]

266. Stock, V.; Fahrenson, C.; Thuenemann, A.; Dönmez, M.H.; Voss, L.; Böhmert, L.; Braeuning, A.; Lampen, A.; Sieg, H. Impact of Artificial Digestion on the Sizes and Shapes of Microplastic Particles. Food Chem. Toxicol. 2020, 135, 111010. [CrossRef]

267. Boag, A.H.; Colby, T.V.; Fraire, A.E.; Kuhn, C.I.; Roggli, V.L.; Travis, W.D.; Vallyathan, V. The Pathology of Interstitial Lung Disease in Nylon Flock Workers. Am. J. Surg. Pathol. 1999, 23, 1539. [CrossRef] 
268. Eschenbacher, W.L.; Kreiss, K.; Lougheed, M.D.; Pransky, G.S.; Day, B.; Castellan, R.M. Nylon Flock-Associated Interstitial Lung Disease. Am. J. Respir. Crit. Care Med. 1999, 159, 2003-2008. [CrossRef]

269. Warheit, D.B.; Hart, G.A.; Hesterberg, T.W.; Collins, J.J.; Dyer, W.M.; Swaen, G.M.H.; Castranova, V.; Soiefer, A.I.; Kennedy, G.L. Potential Pulmonary Effects of Man-Made Organic Fiber (MMOF) Dusts. Crit. Rev. Toxicol. 2001, 31, 697-736. [CrossRef]

270. Schwabl, P.; Köppel, S.; Königshofer, P.; Bucsics, T.; Trauner, M.; Reiberger, T.; Liebmann, B. Detection of Various Microplastics in Human Stool. Ann. Intern. Med. 2019, 171, 453-457. [CrossRef]

271. Ragusa, A.; Svelato, A.; Santacroce, C.; Catalano, P.; Notarstefano, V.; Carnevali, O.; Papa, F.; Rongioletti, M.C.A.; Baiocco, F.; Draghi, S.; et al. Plasticenta: First Evidence of Microplastics in Human Placenta. Environ. Int. 2021, 146, 106274. [CrossRef] 